\title{
Institutional Determinants of International Equity Portfolios - A Country-Level Analysis
}

Barbara Berkel

61-2004 


\title{
Institutional Determinants of International Equity Portfolios - A Country-Level Analysis
}

\author{
Barbara Berkel* \\ MEA, University of Mannheim \\ First version: March 15, 2004 \\ This version: November 1, 2004
}

\begin{abstract}
Despite large potential gains, international equity investment is less diversified across countries than predicted by the international version of the traditional capital asset pricing model (ICAPM). This paper provides empirical evidence on the impact of capital market frictions on international equity portfolios using data on bilateral equity holdings. Two important findings are reported: First, besides a home bias in equities, a 'friendship bias' can be observed for some country pairs. Second, indirect barriers such as the degree of financial market development and especially information asymmetries have strong explanatory power, whereas direct barriers such as capital flow restrictions have no impact on the portfolio share of foreign equities.
\end{abstract}

Keywords: international portfolio diversification, capital market frictions, information asymmetries, ICAPM

JEL classification: G11, G15, F21, F36

*Barbara Berkel, MEA, University of Mannheim, 68131 Mannheim, Germany, email: berkel@mea.uni-mannheim.de

I would especially like to thank Axel Börsch-Supan and participants of the 31st Annual Meeting of the EFA, of the CFS International Macroeconomics Summer School as well as of the seminars at MEA and University of Mannheim. Financial support by the Volkswagen Foundation is gratefully acknowledged. 


\section{Introduction}

Despite large potential gains, international equity investment is less diversified across countries than predicted by the international version of the traditional capital asset pricing model (ICAPM) based on Sharpe (1964) and Lintner (1965). According to the ICAPM, individuals should hold equities from countries around the world in proportion to their market capitalizations. However, empirical facts reveal that international portfolios are heavily biased towards domestic assets. This phenomenon - known as the 'home bias puzzle' - is one of the most striking empirical results in international economics. Table 1 shows that in 2001 U.S. investors held almost 90 percent of their portfolios in domestic equity compared to a world market capitalization of U.S. equity of only 50 percent. For some countries this bias is even more pronounced, for example 67.8 percent compared to 3.9 percent for Germany and 85.9 percent compared to 1.25 percent for Spain. ${ }^{1}$ If one considers the European Monetary Unition (EMU) as one large financial unit the home bias phenomenon is also very pronounced: Investors hold 80.9 percent whereas market capitalization of the euro area amounts to 15.2 percent.

This phenomenon has already attracted a large body of theoretical and empirical research. Lewis $(1995,1999)$ and Karolyi and Stulz (2003) provide extensive reviews of the recent international economics and finance literature. However, the puzzle is not yet fully explored. This is partly due to the lack of data on crossborder holdings. Existing studies are either limited to U.S. foreign equity holdings or focus on countries' total foreign equity holdings not subdivided into country pairs. This paper employs a recently available dataset on bilateral equity holdings, the Coordinated Portfolio Investment Survey (CPIS) of the International Monetary Fund (IMF). Bilateral equity holdings in 38 countries for two available points in time, 1997 and 2001, are used as well as quantitative measures of direct and indirect institutional barriers to international investment.

The aim of the paper is twofold: First, it gives a comprehensive insight into bilateral equity holdings for a large cross section of 38 developed and emerging economies. Second, the impact of capital market frictions on equity holdings is studied. Direct barriers to investment include transaction costs such as capital controls; indirect barriers are based on information asymmetries and the development of financial markets. The paper provides new evidence on the relevance of capital market frictions for equity holdings using a large cross section of country pairs. Thereby it achieves to give some institutional explanations of the home bias phenomenon. ${ }^{2}$

\footnotetext{
${ }^{1}$ For earlier years French and Poterba (1991), Cooper and Kaplanis (1994), Tesar and Werner (1995) as well as Ahearne, Griever and Warnock (2004) for the U.S. report similar levels of bias towards home equity investment.

${ }^{2}$ As opposed to institutional explanations, individual investor behavior such as familiarity,
} 
This paper focuses on equity holdings in a bilateral sense. An important assumption of the ICAPM theory is that there are no barriers to international investment. Therefore, the theoretically predicted share of foreign assets at the country level is calculated and compared to the actual share observed in the data. The discrepancy between these two values is then taken to investigate the relevance of different capital market frictions. The approach is based on the one applied by Ahearne, Griever and Warnock (2004) and Edison and Warnock (2004). This paper contributes to the literature by extending the analysis of the home bias in equities to a large cross section of country pairs.

Many explanations of the extent of foreign equity shares and of the home bias phenomenon have been discussed in the literature. Direct barriers are not able to explain a great extent of the observed home bias. This reflects the fact that more and more countries have abolished capital controls and other direct barriers while significant indirect barriers to international investment remain (Karolyi and Stulz 2003). In line with this literature, this paper finds that the existence of capital controls has no impact on the share of foreign equity investment, which, however, might be due to low data quality. Indirect barriers such as information advantages measured by geographical proximity as well as by the existence of a common legal origin or alternatively of a common colonial relationship have great explanatory power: Coefficients are highly significant and large in size. The paper shows that further indirect barriers such as the degree of financial market development in the country of origin and in the country of destination have a significant impact on the portfolio share of foreign equity investment as well. Moreover, diversification considerations seem to be existent.

Section 2 theoretically discusses the relevance and measurement of capital market frictions for the composition of international equity portfolios. Section 3 refers to the data used in the empirical approach and provides some descriptive statistics of portfolio compositions across countries. Based on the insights of Section 2, Section 4 outlines the empirical model. The results are presented in Section 5. Finally, Section 6 concludes.

\section{Capital Market Frictions - Motivation and Literature Overview}

There are several reasons why it is useful to investigate the impact of capital market frictions on the composition of international equity portfolios. First,

probability judgments and social identity have also been considered in the literature to explain part of this phenomenon. The distinction between institutional and behavioral explanations was first suggested by French and Poterba (1991). 
globalization in general is likely to lead to increased capital mobility and foreign equity investments in order to exploit benefits. ${ }^{3}$ The identifiction of the relevance of capital market frictions gives further insight into the future changes in portfolios. Second, especially in the course of the ongoing integration process in the European Union the portfolio composition is likely to change due to the joining Eastern European countries. Third, given severe demographic changes in many countries, especially in European countries and Japan, the direction of capital flows will change. It is crucial for the estimation and prediction of future investments to know more about the effect of capital market frictions and the extent of capital mobility. ${ }^{4}$ Simulation models predicting international capital flows induced by population aging usually consider scenarios of perfect capital mobility within different regions. ${ }^{5}$ Descriptive statistics in Section 3.2 indicate that capital mobility within the EMU is very high compared to other regions.

Different models and empirical studies consider institutional capital market frictions in order to explain some extent of the phenomenon of home bias in equity holdings and the volume of international capital flows. This literature is reviewed to derive measures of the capital market frictions hypotheses for the subsequent empirical investigation. The most important aspect of frictions are information asymmetries which are broadly discussed followed by a presentation of the relevance of financial development and direct barriers such as capital controls. ${ }^{6}$

\subsection{Information Asymmetries}

Asymmetric information is regarded as a key factor in explaining the empirical evidence on foreign asset holdings and international capital flows. Differences in accounting standards, disclosure requirements and regulatory environments across countries lead to information asymmetries between local and foreign investors. Foreign investors have to translate and interprete this information in light of the relevant legal conventions and business culture which leads to additional costs.

There are some papers that indirectly provide evidence of the effect of information asymmetries on equity investment. Gehrig (1993) models the effect of asymmetric information between domestic and foreign investors using a noisy ra-

\footnotetext{
${ }^{3}$ See Obstfeld (1995) on the benefits and measuring of international capital mobility.

${ }^{4}$ Lührmann (2003) estimates and predicts international capital flows induced by population aging and takes account of several capital market frictions.

${ }^{5}$ See Börsch-Supan, Heiss, Ludwig and Winter (2003).

${ }^{6}$ Frictions caused by nontradable goods are not considered in this context as the impact of the existance of nontradable goods on cross-border equity holdings is hardly empirically measurable with our approach. Lewis (1999) tested implications of nontradable models based on complete markets and showed that these models are not able to explain the home bias.
} 
tional expectations model. In his model investors observe noisy signals of firms' returns with different degrees of precision. It is assumed that on average domestic investors receive signals of future returns that are more precise. Even in equilibrium, investors remain incompletely informed. Under these assumptions a domestic bias arises. Based on the same noisy rational expectations approach Brennan and Cao (1997) build a model of the impact of asymmetric information between domestic and foreign investors on capital flows. They obtain some empirically testable hypotheses on the relationship between returns on national market indices and portfolio flows which are weakly supported by their data.

Kang and Stulz (1997) find that foreign investment in Japanese equities is concentrated in the largest firms as foreign investors have less information about small firms than local investors. They create a model that reveals a home bias in equities in the case of a higher return uncertainty with respect to the foreign market. The implications of their model are consistent with asset allocations of foreign stock ownerships in Japan.

There is a recently growing literature on measuring directly the impact of information asymmetries on equity holdings and flows. Ahearne, Griever and Warnock (2004) proxy information asymmetries by the fraction of public listings of international company stocks at U.S. stock exchanges. Information barriers are reduced as U.S.-listed equities have adopted U.S. accounting standards, disclosure requirements and the U.S. regulatory requirements. ${ }^{7}$ In their cross-country study they find a strong relationship between a country's relative share of cross border listings and the relative weight in U.S. equity portfolios. They conclude that information asymmetry has a major impact on U.S. investors' portfolios and that it is more important than direct barriers to international investment such as capital controls. At a security-level Edison and Warnock (2004) also find that cross-listings at U.S. exchanges have a very strong impact on U.S. investors' portfolio choices of foreign equity. Both empirical studies support the argument that information costs play an important role in the equity investment decision of U.S. investors.

In the economics literature Portes and Rey (2004), Ghosh and Wolf (2000), and Di Giovanni (2004) use 'gravity-models' to explain cross-border capital flows between countries. $^{8}$ Martin and Rey (2004) construct a 'gravity-model' where assets are imperfect substitutes and supply of assets is endogenous. They assume

\footnotetext{
${ }^{7}$ To publicly issue debt or list at U.S. stock exchanges, a foreign firm must reconcile its accounts with U.S. Generally Accepted Accounting Principles (GAAP) and subject itself to the associated regulatory burden. The U.S. GAAP allow investors to compare companies more easily across industries, irrespective of geography. Therefore this adopted measure reduces information costs to U.S. investors.

${ }^{8}$ Portes and Rey (2004) investigate international equity flows, Di Giovanni (2004) cross border M\&A activity and Ghosh and Wolf (2000) FDI, bank lending, portfolio debt and portfolio equity.
} 
the existence of costs that capture transaction costs and information asymmetries between two countries, which are then proxied by geographical distance. The model implies that gross bilateral asset flows will be greater the smaller the distance. In addition to the distance variable, information frictions are also captured by using variables measuring directly the degree of asymmetry between domestic and foreign investors such as the volume of telephone traffic and the number of bank branch subsidiaries, as well as an index of insider trading. For a large cross-section of countries the geographical component in explaining the volume and direction of international capital flows dominates.

Pointing into the same direction, Coval and Moskowitz (1999) provide evidence that there exists a preference for geographically proximate investments even in U.S. investors' portfolios of domestic equity. The importance of distance has been referred to as the 'distance puzzle'. Aviat and Coeurdacier (2004) argue that distance affects bilateral asset holdings ${ }^{9}$ mainly through its impact on trade in goods. Once the impact of trade in goods on equity holdings is taken into account, distance is not very important anymore as an explaining factor for equity holdings. The open question, why asset portfolios are induced by trade in goods, has not yet been fully solved by economic theory so far.

Information advantages do not only arise due to geographical proximity but also due to similar institutions and legal structures. Legal rights of investors differ very much across countries. A large part of this variation is accounted for by legal origin. This applies especially to commercial laws for the financing of firms and for investment but also to law enforcement (La Porta, de Silanes, Shleifer and Vishney 1997, 1998). Laws from different countries are typically not written from scratch but rather transplanted - voluntarily or enforced - from a few legal families or traditions. In general, commercial laws stem from two broad traditions: common law and civil law. A proxy for reduced information asymmetries is the same legal origin of countries, where German, French, Scandinavian civil law families, the English common law and the Socialist law family are distinguished. In a gravity model framework Vlachos (2004) investigates the effect of regulatory harmonization. He provides evidence that bilateral differences in securities regulation and investor protection have large effects on the integration of securities markets.

The similarity of institutions can also be proxied by the fact that two countries share a common colonial background. Colonialism explains the building of institutions for several, although not all, countries (Acemoglu, Johnson and Robinson 2002) ${ }^{10}$ Information advantages arise due to the similarity of institu-

\footnotetext{
${ }^{9}$ Aviat and Coeurdacier (2004) employ stocks as opposed to flows.

${ }^{10}$ Acemoglu et al. (2002) explain income distribution across former colonies by the degree of urbanization and population density: Sparsely populated countries or regions induced Europeans to settle in large numbers and to develop institutions encouraging investment.
} 
tions between colony and colonizer.

The subsequent empirical investigation employs distance as a measure to proxy the costs of obtaining information about foreign markets. Distance is supposed to have a negative impact on foreign equity holdings. To account for a reduction of information costs due to cultural proximity a dummy variable for two countries that are member of the same legal family and alternatively a dummy variable for two countries sharing a common language or a common colonial background are considered. Both dummy variables are expected to have a positive impact on portfolio shares of foreign equities.

\subsection{Financial Market Development}

Financial markets and financial intermediaries play an important role for domestic as well as international investments by mobilizing savings, allocating credit, and facilitating hedging, pooling and pricing of risks. In larger and more liquid markets market prices are supposed to be more informative. One reason is that larger markets encourage arbitrage through liquidity, the existence of more and better substitutes to use as hedges for trading against mispriced securities and reduced transaction costs. ${ }^{11}$ Common proxies for financial development such as the size and depth of the domestic capital market are the amount of private credit provided by the banking sector or the ratio of M2 to GDP. ${ }^{12}$

Efficient investment, and hence an efficient allocation of capital, not only depends on the investors' ability to distinguish promising investment opportunities from mediocre ones. The protection of investor rights and the quality of the legal environment of a country ensures that investors actually invest in the most efficient opportunities. La Porta, de Silanes, Shleifer and Vishney (1998) provide evidence that investor protection and the quality of the legal environment have large effects on the size and breadth of capital markets across 175 developed and developing countries from 1960 to 1997. Most firms in countries with poor investor protection are controlled by large shareholders, so that only a fraction of the shares issued by firms in these countries can be freely traded and held by investors. Dahlquist, Pinkowitz, Stulz and Williamson (2003) show that the share of a country's equities in the stock portfolio of U.S. investors is negatively related to the share of the stock market capitalization of the country held by large shareholders.

Following the literature, the amount of private credit provided by the banking sector relative to GDP is employed in order to account for the development of

\footnotetext{
${ }^{11}$ See Beck, Demirgük-Kunt and Levine (2001) and Wurgler (2000)

${ }^{12}$ See for example Edison and Warnock (2004), Portes and Rey (2004), Portes, Rey and Oh (2001) Di Giovanni (2004) as well as Ahearne, Griever and Warnock (2004).
} 
the financial sector in the source country as well as the country of origin. It is expected to have a positive impact on foreign equity holdings. As a proxy for investor rights and the liquidity of the market the float portfolio calculated in Dahlquist et al. (2003) is considered. The float portfolio is the market capitalization of a country exclusive of closely-held shares by controlling shareholders. It is expected to have more explaining power for investors' portfolio shares than the usual market capitalization.

\subsection{Direct Barriers}

Information asymmetries and financial market development determine the investor's decision in an indirect manner. Direct barriers such as capital controls that have an immediate impact on the net investment return and therefore on the investment decision are also considered.

Although in the 1990s, capital controls have been reduced to a great extent they are still existent today. These controls encompass a wide range of different and often country-specific measures on either capital inflows or outflows. The crucial question is, whether controls that are in place are in fact effective. ${ }^{13}$ This leads to difficulties in measuring the actual degree of investment restrictions for a large cross section of countries. Most measures of capital controls that are available for a large cross section of countries are based on the IMF's Annual Report on Exchange Arrangements and Exchange Restrictions (AREAER) and do not or hardly take the effectiveness of capital controls into account. ${ }^{14}$

Overall, the recent literature suggests that direct capital market frictions are not irrelevant but have only a minor impact compared to indirect frictions. ${ }^{15}$ Given the limited data availability on the intensity of capital controls for the large set of countries in my sample, I use a financial openness measure that was for the first time provided by Grilli and Milesi-Ferretti (1995) based on the IMF's AREAER. ${ }^{16}$ This index is expected to have a negative impact on portfolio shares both, for the country of origin as well as for the country of destination.

\footnotetext{
${ }^{13}$ For a detailed description of different types of capital controls and their effectiveness see Edison et al. (2002) and Neely (1999); for different country experiences see Ariyoshi et al. (2000).

${ }^{14}$ Although there have been attempts to determine measures of the effectiveness of capital controls, these are only available for a limited number of countries or years. See, e.g., Edison et al. (2002) for a comprehensive overview of capital control measures.

${ }^{15}$ See recent empirical results e.g. in Ahearne, Griever and Warnock (2004) and Di Giovanni (2004). A more detailed discussion can be found in Karolyi and Stulz (2003).

${ }^{16}$ As an alternative to capital control measures, Bekaert, Campbell and Lumsdaine (2002) determine liberalization dates for countries' financial markets. Di Giovanni (2004) provides evidence that liberalization dates for the source country indeed have a significant impact on cross border M\&A activity. However, in my sample no liberalizations take place.
} 


\section{Data Description}

\subsection{Data}

So far, reliable bilateral holdings data has hardly been available except for the results of some smaller surveys of residents' portfolio holdings such as for the U.S. in 1994 and $1997 .{ }^{17}$ Cross country equity holdings are obtained from the Coordinated Portfolio Investment Survey (CPIS) of the International Monetary Fund (IMF). For the first time this data set includes comparable portfolio holdings data from as many countries around the world as possible. The survey has been undertaken twice: a first wave in 1997 with 29 countries only and a second wave in 2001 including 64 countries. Further waves are following in the near future.

The CPIS data refers to end of year numbers and includes amongst other things information on gross bilateral foreign equity holdings, securities and for some countries separately reported liabilities. Foreign equity holdings include cross border investment from all sectors: monetary authorities, general government, banks and other financial intermediaries, nonprofit organizations, and households. ${ }^{18}$ The IMF provides the definitions and concepts ${ }^{19}$ whereas the data is organized by domestic statistical institutions, as each country should take account of its own particular financial structure and circumstances. The greatest difficulty consists in capturing cross border investments by households. There are some differences in reporting equity holdings for the 1997 and 2001 waves. In 1997 the distinction between unavailable and zero was not made. Therefore, the two years are treated separatly for the estimations.

Information on countries' total market capitalizations is taken from the World Development Indicators (WDI, 2002) and the International Federation of Stock Exchanges $(\mathrm{FIBV}) .{ }^{20}$ An alternative measure of market capitalizations, the liquidity adjusted float portfolio, can be found in Dahlquist et al. (2003). Data on GDP growth is obtained from WDI (2002).

In order to measure information frictions the physical distance between countries' capital cities and alternatively the fact whether two countries share a common border is used. Moreover, a dummy variable is added that is equal to one if

\footnotetext{
${ }^{17}$ This data has been used for an analysis of the home bias in equities phenomenon for U.S. investors by Ahearne, Griever and Warnock (2004). The 1997 data is also part of the CPIS, as national agencies are asked to provide the bilateral holdings data.

${ }^{18}$ Note that equity investment that establishes a direct investment relationship is excluded from the CPIS. See the definition in the IMF's Balance of Payments Manual, fifth edition (BPM5) and the IMF's Coordinated Portfolio Investment Survey Guide.

${ }^{19}$ These have to be in conformity with the BPM5.

${ }^{20}$ The availability of stock market measures limits the amount of countries in our sample to 38 .
} 
two countries share a common language or have a common colonial background. All these data are based on the CIA factbook ${ }^{21}$ and obtained from Frankel, Stein and Wei (1995). A dummy variable is included to account for if two countries belong to the same legal familiy. This data is obtained from La Porta et al. (1998). To measure the degree of financial market development the amount of domestic credit provided by the banking sector relative to GDP is used. This measure is obtained from WDI (2002).

Capital controls are taken account of by using an updated index by Grilli and Milesi-Ferretti (1995) based on the IMF's Annual Report on Exchange Arrangements and Exchange Restrictions (AREAER). The capital control data refers to the home country as well as to the country of destination. Unfortunately, the data does not allow a clear separation of restrictions on inflows or outflows. Thus, the same indicator, restrict ${ }_{i, t}$ and restrict $_{j, t}$ respectively, is included for both countries.

In 1997 as well as in 2000/01 there have been several banking crises such as for example in Thailand, Malaysia and Turkey. This is taken into account by a dummy variable that is equal to one if a banking crisis as documented in Caprio and Klingebiel (2003) exists in the relevant or precedent year.

Stock returns are considered using standard national stock market indices by Morgan Stanley Capital International (MSCI).$^{22}$ In order to proxy investors' diversification motives monthly returns lagged by one quarter are used to calculate return correlations between two countries and historical risk adjusted excess returns.

The regional classification of the countries is shown in Table 3. It is based on the UN geographical region division and used to construct region dummies. ${ }^{23}$

Appendix $\mathrm{C}$ includes a table with all variables and detailled descriptions of their sources and exact calculations. In Table 5 descriptive statistics of all variables are summarized.

\subsection{Descriptive Statistics}

For all countries around the world with existing stock markets a home bias in equities with respect to total home versus foreign investment can be observed. Table 1 presents the magnitude of this home bias for some selected countries. In addition, there exists a home bias at the country pair level for most cases indicating that investors hold - compared to the International Capital Asset Pricing

\footnotetext{
${ }^{21}$ See www.cia.gov/cia/publications/factbook/.

${ }^{22}$ For all available countries I use the gross index including dividend payments in U.S. dollars.

${ }^{23}$ See http://unstats.un.org/unsd/methods/m49/m49region.htm.
} 
Model (ICAPM) - too little of their portfolio in foreign equities of a given country. Table 2 presents bilateral equity portfolio shares for selected countries (France, Germany, Japan, UK, the U.S. and EMU). For the U.S. this bilateral equity home bias is existent for all country pairs and has been amply discussed in the literature. In contrast, one can observe a bilateral 'friendship bias' for some other country pairs. This bilateral 'friendship bias' states that more than the portfolio share predicted by the ICAPM is held. The phenomenon applies especially to a number of country pairs within the EMU where capital market integration is very advanced.

\section{Empirical Model and Estimation}

The empirical approach is based on the idea of comparing the portfolio share of foreign equities predicted by the International Capital Asset Pricing Model (ICAPM) based on the assumption of perfectly integrated capital markets to the empirical share in a world with capital market frictions. The discrepancy between these two measures is then explained by direct and indirect barriers to international investment at the country-level. ${ }^{24}$

In order to derive an empirical model two different classes of theoretical capital asset pricing models are considered: first, the ICAPM without capital market frictions and, second, an ICAPM with barriers to international investment. ${ }^{25}$

The first class of models goes back to Sharpe (1964) and Lintner (1965). The traditional version of the ICAPM is built on the assumption that investment and consumption opportunity sets do not differ across countries. Investors are the same across countries with respect to risk-aversion and information. These models assume perfect markets. The fact that countries use different currencies has no significant impliciations for portfolio choice and asset pricing. There are no taxes, no tariffs, no information asymmetries, no restrictions on short-sales and no barriers to international investment. One convenient property of this traditional version of the CAPM is that it has simple and clear implications for investors' asset holdings: Investors hold the world market portfolio of risky assets irrespective of their country of residence $i$. It follows that the portfolio share of country $i$ invested into country $j, W_{j}^{*}$, can be expressed as:

\footnotetext{
${ }^{24}$ It is not explicitly taken account of behavioral frictions such as familiarity, individual probability judgments or social identity. At the aggregated country-level, behavioral familiarity effects can hardly be separated from indirect institutional barriers such as information asymmetries, both from an empirical and a theoretical point of view.

${ }^{25}$ See Stulz (1995) for a detailed review of the capital asset pricing literature and a systematic discussion of different models.
} 


$$
W_{j, t}^{*}=\frac{M C A P_{j, t}}{M C A P_{w o r l d, t}}, \forall i
$$

where $M C A P_{j, t}$ denotes market capitalization of country $j$ and $M C A P_{\text {world, } t}$ world market capitalization in period $t$. This market portfolio share serves as the benchmark case of portfolio holdings to which the actual portfolio share that can be observed in the data is compared.

The second class of models by Black (1974), Stulz (1981), Merton (1987) and Cooper and Kaplanis (1994) relaxes the assumption of perfect markets. ${ }^{26}$ These models include frictions that are typically modelled as a deadweight cost or a tax on expected returns in the foreign country. ${ }^{27}$ Investment costs are proxied by indicators of capital market frictions as discussed in Section 2.

Given the two classes of models, the following relationship between observed portfolio shares, $W_{i j, t}^{a c t}$, and the market portfolio share, $W_{j, t}^{*}$, is considered: ${ }^{28}$

$$
W_{i j, t}^{a c t}=\alpha_{0, t}+\alpha_{1, t} W_{j, t}^{*}+C_{i, t}^{\prime} \beta_{1, t}+C_{j, t}^{\prime} \beta_{2, t}+C_{i j, t}^{\prime} \beta_{3, t}+Z_{i j, t} \gamma_{t}+\epsilon_{i j, t} .
$$

The optimal share of investment in the ICAPM with perfect markets, $W_{j, t}^{*}$, enters the right hand side. If the empirical model is able to account for all capital market frictions $\alpha_{1}$ should be equal to one. As discussed in Section 2.2, a liquidity adjusted measure of the stock market capitalization of the destination country, $W_{j, t}^{\text {float }}$, instead of $W_{j, t}^{*}$ is considered in some specifications.

$C_{i, t}, C_{j, t}$ and $C_{i j, t}$ are vectors of indicators for capital market frictions with respect to the country of origin $i$, the country of destination $j$ or the country pair $i j .{ }^{29}$ These vectors consist of variables that take account of information frictions, financial development and direct barriers to investment. The following variables are included to capture information frictions: (1) the logarithm of distance between country $i$ and country $j$, logdistance $_{i j, t}$, (2) a dummy variable equal to one if a country pair has a common legal origin, samelegor ${ }_{i j, t}$. Next, variables

\footnotetext{
${ }^{26}$ Besides explicitly modelling investment barriers, deviations from the optimal portfolios in the case of the traditional ICAPM mentioned above can arise due to deviations from purchasing power parity such as in the model by Adler and Dumas (1981). However, Cooper and Kaplanis (1994) show empirically that large parts of the home bias in equity puzzle cannot be explained by this model

${ }^{27}$ Empirical tests of this class of models have been undertaken in an indirect way so far, see for example Cooper and Kaplanis (1994). Stulz (1995) provides a comprehensive review of emprical tests of ICAPM models with capital market frictions. As opposed to indirect approaches, I address the impact of capital market frictions on portfolio choice directly.

${ }^{28}$ For the exact calculation of actual portfolio shares see Appendix A.

${ }^{29}$ Country of origin denotes the investor's country of residence.
} 
reflecting the degree of financial market development are included: (3) the logarithm of domestic credit provided by the banking sector as a percentage of GDP for the country of origin as well as for the country of destination, logdcredit $t_{i, t}$ and $l o g d c r e d i t_{j, t}$. Direct barriers are added: (4) an index of capital flow restrictions both for the country of origin and the country of destination, restrict $_{i, t}$ and restrict $_{j, t}$. Consequently, frictions such as financial market underdevelopment and capital flow restrictions are attributed to each country separatly whereas information frictions are country pair specific. ${ }^{30}$

In addition, a vector of control variables, $Z_{i j, t}$, is included in order to investigate whether diversification motives lead to higher foreign portfolio shares. Two different proxies are considered that capture different aspects of diversivication. First, a reward-to-risk measure as constructed by Ahearne, Griever and Warnock (2004) is calculated. This variable, $\operatorname{hrar}_{i j, t}$, measures the mean monthly return over its standard deviation. Second, investors are likely to exploit gains from diversifying investments. A correlation variable that is equal to the monthly return correlation, is added, $r \operatorname{rcorr}_{i j, t}$. In order to control for profitable investment opportunities in growing economies, GDP growth for the country of destination is included, gdpgrowt $h_{j, t}$.

Additionally, I account for banking crises by considering a dummy equal to one if a banking crisis was present in the current or antecedent year, crisisbank $_{i, t}$, crisisbank $_{j, t}$. Fixed effects are included via regional dummies for the country of destination and the country of origin. The regional assignment is documented in Table 3. Finally, a constant, $\alpha_{0, t}$, and a nuisance term, $\epsilon_{i j, t}$, are included.

Capital market frictions are likely to have an impact on the perception of expected return differences and return correlations. This effect is taken into account in some specifications by including interactions between indicators for capital market frictions and historical risk adjusted return differences, rar $_{i j, t}$, and return correlations, rcorr $_{i j, t}$. In addition, the hypothesis is tested whether capital market frictions have a different impact in a sample with well integrated markets such as the EMU.

In several cases reported investments are zero. These corner solution outcomes are likely due to an investor's optimization in a world with investment barriers that results in an optimal outcome of zero foreign equity holdings. Consequently, $W_{i j, t}^{a c t}$ is zero. For all other observations the dependent variable is positive and continuous. Therefore, a corner solution model is estimated, where the partial effects of $W_{j, t}^{*}, C_{i, t}, C_{j, t}$ and $C_{i j, t}$ on $E\left(W_{i j, t}^{a c t} \mid W_{j, t}^{*}, C_{i, t}, C_{j, t}, C_{i j, t}\right)$ are of interest. These are obtained by estimating a Tobit model censored at zero and by calculating average adjustment factors for the coefficients of the Tobit regression. ${ }^{31}$

\footnotetext{
${ }^{30}$ For more detailed descriptions of the explaining variables refer to Appendix B.

${ }^{31}$ See Wooldridge (2002), Chap. 16 pp. 521-524 for exact derivations.
} 
This estimation method can be applied to the CPIS data for 2001, but not immediately to the 1997 wave, because in 1997 zeros refer to both true zeros and missing values. In order to provide comparability across regressions for each year and to validate a Tobit estimation approach for the 1997 data, missing values are imputed by using the information of the 2001 wave: A Probit model fitting the probability of a missing or a zero entry given the explaining variables mentioned above is estimated for 2001. The estimation output is reported in Table 4. The estimated coefficients are used to estimate the probability of a zero or missing value for 1997. If the probability of a missing is larger than one half, the reported zero is changed into a missing value.

\section{$5 \quad$ Results}

Basic regression results are reported in Tables 6 to 9. Additional robustness checks can be found in Appendix B. Descriptive statistics of all variables are summarized in Table 5 .

Specifications (1) and (2) in Table 6 summarize basic regression results for 1997 and 2001. Information frictions proxied by logdistance ${ }_{i j, t}$ and samelegor $_{i j, t}$ have highly significant, large coefficients with the expected negative and positive signs. A one percent increase in distance between two countries leads on average to a decrease in the portfolio share of equity holdings of about 0.15 in 1997 and of about 0.27 in 2001, which is the coefficient times the reported average adjustment factor resulting from the Tobit model. If both countries have the same legal origin, the share of foreign equity holdings is on average 0.25 higher in 1997 and even larger in 2001, namely equal to 0.39. This is a very substantial difference to countries not sharing a common legal origin, given that the average value of $W_{i j, t}^{a c t}$ is 0.36 in 1997 and 0.7 in 2001 (Table 5). ${ }^{32}$

Geographical proximity and historical relations facilitate the knowledge of accounting practices, corporate culture, political events, and the structure of asset markets and their institutions. Moreover, cultural exchange and cultural affinities are a component of the network effects that influence international economic interactions. Overall, the results emphasize the importance of information frictions as determinants of international equity portfolios.

The second group of indirect capital market frictions refers to the degree of financial market development in the source country as well as in the country of

\footnotetext{
${ }^{32}$ Robustness checks in Appendix B reveal that instead of using common legal origin as a proxy for information advantages, the fact that two countries share a common language (which is identical to saying that two countries share a common colonial background in our sample) leads to the same strong results. Likewise distance $_{i j, t}$ can be interchanged with a dummy variable equal to one if two countries are part of the same region.
} 
destination, proxied by the corresponding ratios of private credit provided by the financial sector relative to GDP, logdcredit ${ }_{i, t}$ and logdcredit $_{j, t}$. For 1997 the coefficients on both variables are significant and have the expected positive signs. The effect is larger for the country of destination: A one percent increase in the home country's credit to GDP ratio leads to an average increase in the share of foreign equity holdings of 0.17 whereas a one percent increase in the country of destination leads on average to additional 0.22 percentage points of foreign equity holdings of country $i$ in country $j$. In 2001 this effect is slightly larger whereas the home country effect is not significant.

The more developed the financial sector of the foreign country $j$, the more informative are prices and investment opportunities. Investors are more inclined to hold equity shares in that economy. The positive effect of the financial market development in the home country $i$ indicates that more and better financial institutions not only lead to more local financial activity but also to more investments in foreign markets.

If capital controls on incoming capital are in place, the share of foreign equity investment into that country should be lower. Again a negative effect is expected if capital controls on outgoing capital are in place. Neither of these effects is significant in 1997 or 2001. But one has to bear in mind the imprecise quality of the capital control data and the problem of measuring the effectiveness of capital controls.

Control variables are added in order to check further hypotheses. First, there is a tendency to follow higher risk adjusted excess returns in 1997. For 2001 the coefficient is significant but does not reveal a positive sign (Table 6). Once interaction effects are held constant in the 2001 sample [specification (3)], the coefficient on historical risk adjusted return differences, $\operatorname{rrar}_{i j, t}$, is highly significant and has a positive coefficient. ${ }^{33}$ Interactions with frictions such as financial market development in the source country, same legal origin and GDP growth in the foreign country reveal significant effects on foreign portfolio shares. The coefficients on $h r a r * l o g d c r e d i t_{j, t}$ and $h r a r *$ samelegor $_{i j, t}$ are negative which indicates that investors care less about higher risk adjusted excess returns in high developed source markets and markets with similar institutions. ${ }^{34}$ Overall, for both years diversification motives can be identified although results are not very stable across years and specifications.

Second, return correlations, captured by the variable rcorr $_{i j, t}$, have no signif-

\footnotetext{
${ }^{33}$ However, for 1997 the significant impact of risk adjusted return differences, hrar $_{i j, t}$ vanishes if interactions are taken into account; interactions are not significant. All other coefficients do not change.

${ }^{34}$ Moreover, if GDP growth rates are higher, positive risk adjusted excess returns and negative return correlations have larger impacts on foreign portfolio shares. With respect to distance the two interaction effects have ambigious interpretations.
} 
icant effect. ${ }^{35}$ Third, GDP growth is included as an additional control variable for the country of destination. It has a significantly positive impact in 2001 only: A one percent increase in GDP growth leads to an increase in foreign equity holdings of about 0.075 percent.

Common to the above mentioned specifications is the fact that the coefficient of $W_{j, t}^{*}$ is highly significant but very low in size, namely equal to 0.05 for 1997 and 0.08 in 2001 . The effect of the float portfolio share, $W_{j, t}^{\text {float }}$, is slightly smaller for both years. In the full sample the float portfolio share does not seem to capture any further liquidity effects and does not provide any additional explaining power compared to the market portfolio share, $W_{j, t}^{*} \cdot{ }^{36}$ These results show that for a large cross section of countries the implications of the traditional ICAPM are hardly existent. - Does this change when the impact of $W_{j, t}^{*}$ on $W_{i j, t}^{a c t}$ is analyzed for different regions and countries separately?

The size of the coefficients of $W_{j, t}^{*}$ and $W_{j, t}^{\text {float }}$ indeed differs significantly across regions. Table 7 presents regressions including region dummies interacted with the market and the float portfolio share respectively. Compared to the reference region Western Europe the partial effects of the market portfolio share are significantly larger for North America and Northern Europe. For Southern America, East Asia, South East Asia and West Asia partial effects are significantly smaller. ${ }^{37}$ The same picture corresponds to the float portfolio share. Except for Nothern America the results are similar for both years. The largest coefficient can be observed in the 2001 sample for Nothern Europe: A one percent increase in the market capitalization of the source country leads to a in increase in actual foreign portfolio shares by $0.19 .{ }^{38}$

When the two measures of market capitalization are interacted with dummies for the U.S. as a source country and with a dummy for country pairs within the EMU the coefficients of $W_{j, t}^{*}$ and $W_{j, t}^{\text {float }}$ become even larger. For EMU country pairs the effect of $W_{j, t}^{\text {float }}$ is more than three times as large as for the rest of the sample in 2001 (Table 8). There is no significant difference in coefficients for the U.S.

Interestingly, for within-EMU investments the coefficient on $W_{j, t}^{\text {float }}$ is larger than the coefficient on $W_{j, t}^{*}$. This can be observed for the full sample estimations in Table 8 and for a sample refering to within-EMU investments only (Table 9).

\footnotetext{
${ }^{35}$ The tendency to find a positive relationship in 2001 is in line with other empirical studies, e.g. Aviat and Coeurdacier (2004).

${ }^{36}$ If both variables are included at the same time, the coefficient on $W_{j, t}^{\text {float }}$ is insignificant.

${ }^{37}$ The regional classification is documented in Table 3.

${ }^{38}$ Note that partial effects with respect to the full sample, i.e. zero and positive values, are described here. If partial effects for the sample with positive foreign portfolio shares are of interest the marginal impacts of $W_{j, t}^{*}$ and $W_{j, t}^{\text {float }}$ are almost twice as large.
} 
Within the EMU an increase in $W_{j, t}^{*}$ by one percentage point leads in 1997 to an increase in the portfolio share by 27 percentage points whereas a similar increase in $W_{j, t}^{\text {float }}$ leads to a portfolio share that is 34 percentage points higher (Table 9 ). For 2001 the average partial effects are 51 and 67 percentage points respectively. ${ }^{39}$ If one limits this interpretation to partial effects of positive observed portfolio shares the hypothesis of $W_{j, t}^{*}$ being equal to one can not be rejected for the 2001 sample. The results show that in a well integrated market such as this sub-sample of within-EMU investments the world market portfolio and the float portfolio share have a very large effect on actual portfolio shares and the implication of the traditional ICAPM comes out very well.

For the sample of within EMU investments only, information frictions are still existent but only with respect to distance. The degree of financial market development of the source country matters only for 1997 but not any more for 2001. Financial market development of the home country does not matter in 1997 whereas in 2001 it has a significant and large negative impact as opposed to the positive coefficients in the full sample estimations. This could be due to the fact that highly developed financial markets have better diversification possibilities within their own countries and are therefore less inclined to hold foreign equities. This effect might dominate in a sample of relative homogeneous financial markets and lead to a negative coefficient. Finally, diversification motives are present but not stable across years.

\section{Conclusion}

This paper employs a recently available data set, the IMF's Coordinated Portfolio Investment Survey, in order to investigate the institutional determinants of international equity portfolios. The large cross section of the data itself allows to report some interesting facts about international bilateral equity holdings: While a home bias in equities can be observed for most country pairs including the U.S., the data reveals a bilateral 'friendship bias' for several other country pairs, mostly countries within the same geographical region, in particular within the EMU.

The aim of the paper is to provide evidence on the impact of capital market frictions on foreign equity holdings. The corresponding empirical hypotheses are derived from the finance and international economics literature. Direct capital market frictions include capital controls while indirect barriers encompass information asymmetries and the degree of financial market development. Capital

\footnotetext{
${ }^{39}$ Similarly, for the U.S. Dahlquist et al. (2003) show that the coefficient on $W_{j, t}^{\text {float }}$ is larger than on $W_{j, t}^{*}$.
} 
market frictions altogether are expected to contribute to a lower portfolio share in overall foreign equities. The empirical model is based on the difference between actual equity portfolio shares and the ones predicted by the ICAPM under the assumption of perfect capital markets.

The estimation results reveal that especially information asymmetries, proxied by geographical proximity and the existence of a common legal origin or, alternatively, by the existence of a common language or a common colonial background, have very large and significant impacts on the composition of international equity portfolios. Financial development measured as the amount of credit provided by the banking sector relative to GDP also has large positive effects on the share of bilateral equity portfolios. This is true for the country of destination as well as for the country of origin. The impact of financial market development is, however, less important, i.e. smaller and less significant, across specifications compared to the impact of information advantages.

By contrast, capital controls do not play any role in determining equity portfolios. A similar result has been emphasized also by Ahearne, Griever and Warnock (2004). However, in this paper these results might be partly due to the relatively low quality of the capital controls data.

In addition, diversification considerations of investors and their relations to capital market frictions are investigated. Higher risk adjusted excess returns have a positive impact on foreign portfolio shares in several specifications. In some cases this is revealed only after controlling for interactions between capital market frictions and excess returns. Diversification considerations reflected by negative return correlations can hardly be found in the data.

Liquidity constraints due to controlling shareholders, i.e. the availability of shares issued by firms in a country, are taken into account by using an alternative float portfolio instead of the market portfolio share as an explaining variable. However, for the full sample there are no significant differences between these two measures. For within-EMU investments the coefficient of the float portfolio has additional explaining power.

The sample consists of 38 countries and includes about 1800 observations on bilateral equity portfolio shares for two years, 1997 and 2001. Robustness checks suggest that the main results are very stable for different subsamples excluding major financial centers as well as for different specifications and estimation techniques. Years are estimated separately due to reporting changes. There are differences mostly with respect to the size of the coefficients across the two years. However, the main conclusions apply to both subsamples.

The results in this paper reveal a strong impact of indirect capital market frictions on international equity holdings and therefore go part of the way in 
explaining the home bias in equity phenomenon and the 'friendship bias' that is documented for some country pairs. The geographical patterns in international equity portfolios and the importance of information asymmetries established in this paper are similar to the results obtained by 'gravity model' approaches. These findings suggest a more detailed look at the linkage between capital flows, equity holdings and diversification. Besides, further research is needed to base the empirical evidence on a more sophisticated theoretical model that demonstrates the impact of capital market frictions on international equity holdings in an ICAPM framework taking into account diversification considerations of investors. 


\section{References}

Acemoglu, D., S. Johnson and J. A. Robinson (2002): "Reversal of Fortune: Geography and Institutions in the Making of the Modern World Income Distribution". The Quarterly Journal of Economics 117(4): pp. 12311294.

Adler, M. and B. Dumas (1981): "International Portfolio Choice and Corporation Finance: A Synthesis". Journal of Finance 38(3): pp. 925-984.

Ahearne, A. G., W. Griever and F. E. Warnock (2004): "Information costs and home bias: An analysis of U.S. holdings of foreign equities". Journal of International Economics 62: pp. 313-336.

Ariyoshi, A., K. Habermeier, B. Laurens, I. Otker-Robe, J. CanalesKriljenko and A. Kirilenko (2000): "Capital controls: Country experiences with their use and liberalization". IMF Occasional Paper No. 190.

Aviat, A. and N. Coeurdacier (2004): "The Geography of Trade in Goods and Asset Holdings". DELTA, mimeo.

Beck, T., A. Demirgük-Kunt and R. Levine (2001): "The Financial Structure Database". In A. Demirgük-Kunt and R. Levine (Eds.), "Financial structure and economic growth - A cross-country comparison of banks, markets, and development", Ch. 2, The MIT Press, Cambridge, Mass., pp. $17-81$.

Bekaert, G., C. Campbell and R. Lumsdaine (2002): "Dating the integration of world equity markets". Journal of Financial Economics 65(2): pp. 203-248.

Black, F. (1974): "International capital market equilibrium with investment barriers". Journal of Financial Economics 1(1).

Börsch-Supan, A., F. Heiss, A. Ludwig and J. Winter (2003): "Pension Reform, Capital Markets, and the Rate of Return". German Economic Review 4(2): pp. 151-181.

Brennan, M. J. and H. H. Cao (1997): "International portfolio investment flows". The Journal of Finance 52(5): pp. 1851-1880.

Caprio, G. and D. Klingebiel (2003): "Episodes of systemic and borderline financial crisis". World Bank mimeo.

Cooper, I. and E. Kaplanis (1994): "Home Bias in Equity Portfolios, Inflation Hedging, and International Capital Market Equilibrium". The Review of Financial Studies 7(1): pp. 45-60.

Coval, J. and T. Moskowitz (1999): "Home bias at home: Local equity preference in domestic portfolios". Journal of Finance 54(6): pp. 20452073. 
Dahlquist, M., L. Pinkowitz, R. Stulz and R. Williamson (2003): "Corporate Governance and the Home Bias". Journal of Financial and Quantitative Analysis 38(1): pp. 87-110.

Di Giovanni, J. (2004): "What drives capital flows? The case of cross-border M\&A activity". Journal of International Economics, forthcoming .

Edison, H., M. Klein, L. Ricci and T. Sloek (2002): "Capital Account Liberalization and Economic Performance: Suvey and Synthesis". NBER Working Paper No. 9100.

Edison, H. and F. Warnock (2004): "U.S. investors' emerging market equity portfolios: A security-level analysis". Review of Economics and Statistics, forthcoming .

Frankel, J., E. Stein and S. Wei (1995): "Trading Blocs and the Americas: The Natural, the Unnatural and the Supernatural". Journal of Development Economics 47(1).

French, K. R. and J. M. Poterba (1991): "Investor Diversification and International Equity Markets". The American Economic Review 81(2): pp. $222-226$.

Gehrig, T. (1993): "An information based explanation of the domestic bias in international equity investment". Scandinavian Journal of Economics 95: pp. 97-109.

Ghosh, S. and H. Wolf (2000): "Is there a curse of location?" In S. Edwards (Ed.), "Capital flows and the emerging economies", Ch. 5, The University of Chicago Press, Chicago and London, pp. 136-158.

Grilli, V. and G. Milesi-Ferretti (1995): "Economic effects and structural determinants of capital controls". IMF Staff Papers 42(3): pp. 517-551.

Kang, J.-K. and R. M. Stulz (1997): "Why is there a Home Bias? An Analysis of Foreign Portfolio Equity Ownership in Japan". Journal of Financial Economics 46: pp. 2-18.

Karolyi, G. and R. Stulz (2003): Are financial assets priced locally or globally?, Vol. 1B of Handbook of the Economics of Finance. Constantinides, G., M. Harris and R. Stulz.

La Porta, R., F. L. de Silanes, A. Shleifer and R. W. Vishney (1998): "Law and Finance". Journal of Political Economy 106: pp. 1113-1155.

La Porta, R., F. Lopez-de Silanes, A. Schleifer and R. W. Vishny (1997): "Legal Determinants of External Finance". NBER Working Paper No. 5879 .

Lewis, K. K. (1999): "Trying to Explain Home Bias in Equities and Consumption". Journal of Economic Literature 37: pp. 571-608. 
Lintner, J. (1965): "The valuation of risky assets and the selection of risky investment in stock portfolio and capital budgets". Review of Economics and Statistics 47: pp. 103-124.

Lührmann, M. (2003): "Demographic Change, Foresight and International Capital Flows". MEA discussion paper No. 38-03.

Martin, P. and H. Rey (2004): "Financial Super-Markets: Size Matters for Asset Trade". Journal of International Economics, forthcoming .

Merton, R. (1987): "A Simple Model of Capital Market Equilibrium with Incomplete Information". The Journal of Finance 42(3): pp. 483-510.

Neely, C. (1999): "An introduction to capital controls". Review, Federal Bank of St. Louis : pp. 13-30.

Obstfeld, M. (1995): "International Capital Mobility in the 1990s". In P. B. Kenen (Ed.), "Understanding Interdependence", Ch. 6, Princeton, pp. 201-261. Princeton University Press.

Portes, R. and H. Rey (2004): "The determinants of cross-border equity flows". Journal of International Economics, forthcoming .

Portes, R., H. Rey and Y. Oh (2001): "Information and Capital Flows: The Determinants of Transactions in Financial Assets". European Economic Review 45: pp. 783-796.

Sharpe, W. (1964): "Capital asset prices: a theory of market equilibrium under the condition of risk". Journal of Finance 19: pp. 425-442.

Stulz, R. (1981): "On the effects of barriers to international investment". Journal of Finance 36: pp. 923-934.

Stulz, R. (1995): "International Portfolio Choice and Asset Pricing: An Integrative Survey". In R. Jarrow, M. Maksimovic and W. Ziemba (Eds.), "Handbook of Modern Finance", North Hollond, Elsevier, pp. 201-223.

Tesar, L. and I. Werner (1995): "Home bias and high turnover". Journal of International Money and Finace 14: pp. 467-493.

Vlachos, J. (2004): "Does Regulatory Harmonization Increase Bilateral Asset Holdings?" CEPR Discussion Paper 4417.

Wooldridge, J. (2002): Econometric Analysis of Cross Section and Panel Data. Cambridge, Mass.: The MIT Press.

Wurgler, J. (2000): "Financial markets and the allocation of capital". Journal of Financial Economics 58: pp. 187-214. 
Table 1: Home Bias in Equities in 2001

\begin{tabular}{ccc}
\hline \hline & $\begin{array}{c}\text { \% of equity assets } \\
\text { in domestic equities }\end{array}$ & $\begin{array}{c}\text { share of world } \\
\text { market capitalization }\end{array}$ \\
\hline US & 89.22 & 50.64 \\
Japan & 89.50 & 8.26 \\
UK & 74.73 & 8.13 \\
Germany & 67.81 & 3.93 \\
France & 79.80 & 4.31 \\
Spain & 85.94 & 1.25 \\
EMU & 80.93 & 15.19 \\
\hline \hline
\end{tabular}

Source: Foreign equity investments from the IMF's CPIS, market capitalizations from WDI (2002) and FIBV, own calculations. 
Table 2: Bilateral Equity Portfolio Shares of Selected Countries in 2001

\begin{tabular}{|c|c|c|c|c|c|c|c|}
\hline \multirow[b]{2}{*}{ country $_{j}$} & \multirow{2}{*}{$\begin{array}{c}\text { share of world } \\
\text { market capitalization }\end{array}$} & \multicolumn{6}{|c|}{ equity portfolio share invested in country ${ }_{j}$} \\
\hline & & France & Germany & Japan & UK & U.S. & EMU \\
\hline Argentina & 0.71 & 0.00 & 0.00 & 0.00 & 0.02 & 0.01 & 0.02 \\
\hline Australia & 1.37 & 0.04 & 0.05 & 0.14 & 0.54 & 0.26 & 0.15 \\
\hline Austria & 0.09 & 0.01 & 0.09 & 0.00 & 0.06 & 0.01 & \\
\hline Belgium & 0.06 & 0.57 & 0.17 & 0.04 & 0.14 & 0.06 & \\
\hline Brazil & 0.68 & 0.02 & 0.02 & 0.01 & 0.16 & 0.15 & 0.10 \\
\hline Canada* & 2.57 & 0.10 & -0.03 & 0.13 & -0.34 & 0.62 & 0.09 \\
\hline Chile & 0.21 & 0.00 & 0.00 & 0.00 & 0.01 & 0.01 & 0.01 \\
\hline Colombia & 0.05 & 0.00 & 0.00 & 0.00 & 0.00 & 0.00 & 0.00 \\
\hline Denmark & 0.35 & 0.05 & 0.04 & 0.02 & 0.10 & 0.05 & 0.07 \\
\hline Egypt & 0.09 & 0.00 & 0.00 & 0.00 & 0.00 & 0.00 & 0.00 \\
\hline Finland & 0.70 & 0.47 & 1.16 & 0.09 & 0.48 & 0.36 & \\
\hline France & 4.31 & 79.80 & 4.01 & 0.48 & 4.21 & 0.78 & \\
\hline Germany & 3.93 & 2.06 & 67.81 & 0.32 & 2.17 & 0.50 & \\
\hline Greece & 0.32 & 0.01 & 0.01 & 0.00 & 0.06 & 0.02 & \\
\hline Hong Kong & 1.86 & 0.07 & 0.06 & 0.23 & 0.61 & 0.21 & 0.40 \\
\hline Hungary & 0.04 & 0.00 & 0.01 & 0.00 & 0.02 & 0.01 & 0.02 \\
\hline Indonesia & 0.08 & 0.00 & 0.00 & 0.00 & 0.02 & 0.01 & 0.01 \\
\hline Ireland & 0.28 & 0.65 & 0.91 & 0.12 & 0.42 & 0.20 & \\
\hline Israel & 0.21 & 0.01 & 0.02 & 0.00 & 0.01 & 0.09 & 0.02 \\
\hline Italy & 1.93 & 0.96 & 1.10 & 0.14 & 0.83 & 0.23 & \\
\hline Japan & 8.26 & 0.73 & 0.49 & 89.50 & 2.61 & 1.19 & 1.08 \\
\hline Korea, Rep. of & 0.85 & 0.05 & 0.07 & 0.02 & 0.34 & 0.21 & 0.11 \\
\hline Malaysia & 0.44 & 0.01 & 0.01 & 0.02 & 0.07 & 0.02 & 0.02 \\
\hline Netherlands & 1.68 & 2.36 & 2.71 & 0.25 & 1.69 & 0.78 & \\
\hline New Zealand & 0.07 & 0.00 & 0.00 & 0.01 & 0.03 & 0.01 & 0.01 \\
\hline Norway & 0.25 & 0.04 & 0.03 & 0.01 & 0.15 & 0.06 & 0.04 \\
\hline Philippines & 0.08 & 0.00 & 0.00 & 0.01 & 0.01 & 0.01 & 0.00 \\
\hline Poland & 0.10 & 0.00 & 0.01 & 0.00 & 0.02 & 0.01 & 0.03 \\
\hline Portugal & 0.17 & 0.05 & 0.06 & 0.01 & 0.14 & 0.03 & \\
\hline Singapore & 0.43 & 0.02 & 0.03 & 0.04 & 0.24 & 0.15 & 0.06 \\
\hline Spain & 1.72 & 0.99 & 1.18 & 0.13 & 0.93 & 0.23 & \\
\hline Sweden & 0.85 & 0.14 & 0.24 & 0.08 & 0.87 & 0.17 & 0.34 \\
\hline Switzerland & 1.91 & 1.07 & 1.83 & 0.31 & 1.39 & 0.53 & 1.44 \\
\hline Thailand & 0.13 & 0.01 & 0.03 & 0.01 & 0.07 & 0.01 & 0.02 \\
\hline Turkey & 0.17 & 0.00 & 0.01 & 0.00 & 0.02 & 0.02 & 0.01 \\
\hline United Kingdom & 8.13 & 2.58 & 3.76 & 1.37 & 74.73 & 2.44 & 4.12 \\
\hline United States & 50.65 & 4.25 & 5.93 & 5.75 & 6.40 & 89.22 & 7.82 \\
\hline Venezuela & 0.02 & 0.00 & 0.00 & 0.00 & 0.01 & 0.00 & 0.00 \\
\hline
\end{tabular}

*) observation $<0$ reflects short positions in securities usually resulting from the sale of securities acquired under repurchase agreements.

Sources: CPIS for 2001, WDI (2002) and FIBV, own calculations. 
Table 3: Countries and Regions

\begin{tabular}{lll}
\hline \hline & & \\
South America & South East Asia & Northern Europe \\
Argentina & Indonesia & Denmark \\
Brazil & Malaysia & Finland \\
Chile & Philippines & Ireland \\
Colombia & Singapore & Norway \\
Venezuela & Thailand & Sweden \\
& & United Kingdom \\
& & \\
North America & Oceania & Western Europe \\
Canada & Australia & Austria \\
United States & New Zealand & Belgium* \\
& & France \\
West Asia & Eastern Europe & Germany \\
Israel & Hungary & Netherlands \\
Turkey & Poland & Switzerland \\
& & \\
East Asia & Southern Europe & Northern Africa \\
Hong Kong & Greece & Egypt \\
Japan & Italy & \\
Korea, Rep. Of & Portugal & \\
& Spain & \\
\hline \hline
\end{tabular}

*) Belgium refers to Belgium only, excluding Luxemburg. 
Table 4: Probit Estimates of Missing Values in 2001

\begin{tabular}{lc}
\hline \hline $\mathrm{W}_{\mathrm{j}}^{*}$ & 0.02 \\
& $(0.93)$ \\
logdistance $_{\mathrm{ij}}$ & -0.067 \\
& $(0.66)$ \\
samelegor $_{\mathrm{ij}}$ & 0.681 \\
& $(4.10)^{* * *}$ \\
logdcredit $_{\mathrm{i}}$ & -0.223 \\
& $(2.40)^{* *}$ \\
logdcredit $_{\mathrm{j}}$ & 0.043 \\
& $(0.42)$ \\
restrict $_{\mathrm{i}}$ & -0.094 \\
& $(0.93)$ \\
restrict $_{\mathrm{j}}$ & -0.061 \\
& $(0.68)$ \\
hrar $_{\mathrm{ij}}$ & -0.001 \\
& $(0.03)$ \\
rcorr $_{\mathrm{ij}}$ & -0.186 \\
& $(0.64)$ \\
gdpgrowth $_{\mathrm{j}}$ & -1.405 \\
& $(0.2)$ \\
bankcrisis $_{\mathrm{i}}$ & -0.523 \\
& $(3.26)^{* * *}$ \\
bankcrisis $_{\mathrm{j}}$ & -0.095 \\
& $(0.56)$ \\
constant & 2.049 \\
adj. $^{2}$ & $(1.78)^{*}$ \\
\hline \hline & 433 \\
& 0.08 \\
\hline
\end{tabular}

Notes: Dependent variable is equal to one if there exists a missing value and equal to zero if there is a zero value in 2001; Probit estimation. Absolute values of $t$ statistics are reported in parentheses. 
Table 5: Descriptive Statistics

\begin{tabular}{|c|c|c|c|c|c|c|c|c|c|c|}
\hline \multirow[b]{2}{*}{ Variable } & \multicolumn{5}{|c|}{1997} & \multicolumn{5}{|c|}{2001} \\
\hline & Obs. & Mean & Std. Dev. & Min & Max & Obs. & Mean & Std. Dev. & Min & Max \\
\hline $\mathrm{W}_{\mathrm{ij}}^{\mathrm{act}}$ & 900 & 0.36 & 1.25 & 0.00 & 18.86 & 899 & 0.71 & 2.58 & -0.34 & 43.12 \\
\hline $\mathrm{W}_{\mathrm{j}}^{*}$ & 900 & 2.60 & 8.06 & 0.05 & 48.63 & 899 & 3.48 & 9.75 & 0.04 & 50.65 \\
\hline $\mathrm{W}_{\mathrm{j}}^{\text {float }}$ & 900 & 2.68 & 9.63 & 0.02 & 58.32 & 899 & 3.66 & 11.69 & 0.02 & 60.74 \\
\hline $\operatorname{logdistance}_{\mathrm{ij}}$ & 900 & 8.56 & 1.06 & 5.16 & 9.90 & 899 & 8.45 & 1.10 & 5.16 & 9.90 \\
\hline $\operatorname{adjacency}_{\mathrm{ij}}$ & 900 & 0.05 & 0.21 & 0.00 & 1.00 & 899 & 0.05 & 0.22 & 0.00 & 1.00 \\
\hline samelegor $_{\mathrm{ij}}$ & 900 & 0.29 & 0.45 & 0.00 & 1.00 & 899 & 0.26 & 0.44 & 0.00 & 1.00 \\
\hline language $_{i j}$ & 900 & 0.15 & 0.35 & 0.00 & 1.00 & 899 & 0.15 & 0.36 & 0.00 & 1.00 \\
\hline $\operatorname{logdcredit}_{\mathrm{i}}$ & 900 & 4.35 & 0.57 & 2.66 & 5.26 & 899 & 4.43 & 0.60 & 2.48 & 5.23 \\
\hline $\operatorname{logdcredit}_{j}$ & 900 & 4.24 & 0.66 & 2.66 & 5.26 & 899 & 4.42 & 0.62 & 3.02 & 5.23 \\
\hline restrict $_{i}$ & 900 & 0.35 & 0.73 & 0.00 & 3.00 & 899 & 0.43 & 0.70 & 0.00 & 2.00 \\
\hline restrict $_{j}$ & 900 & 0.61 & 0.95 & 0.00 & 3.00 & 899 & 0.44 & 0.72 & 0.00 & 2.00 \\
\hline $\operatorname{hrar}_{\mathrm{ij}}$ & 900 & 0.02 & 0.46 & -1.79 & 1.79 & 899 & -0.01 & 0.28 & -0.76 & 0.76 \\
\hline $\operatorname{rcorr}_{\mathrm{ij}}$ & 900 & 0.00 & 0.02 & -0.06 & 0.21 & 899 & 0.01 & 0.01 & -0.01 & 0.07 \\
\hline gdpgrowth $_{\mathrm{ij}}$ & 900 & 1.39 & 2.39 & -7.39 & 8.54 & 899 & 1.20 & 2.29 & -7.39 & 5.85 \\
\hline bankcrisis $_{i}$ & 900 & 0.16 & 0.36 & 0.00 & 1.00 & 899 & 0.19 & 0.39 & 0.00 & 1.00 \\
\hline bankcrisis $_{j}$ & 900 & 0.14 & 0.35 & 0.00 & 1.00 & 899 & 0.20 & 0.40 & 0.00 & 1.00 \\
\hline
\end{tabular}

Note: $\mathrm{W}_{\mathrm{ij}}^{\text {act }}$ and $\mathrm{W}_{\mathrm{j}}{ }^{*}$ are measured in percent. 
Table 6: Main Regression Results

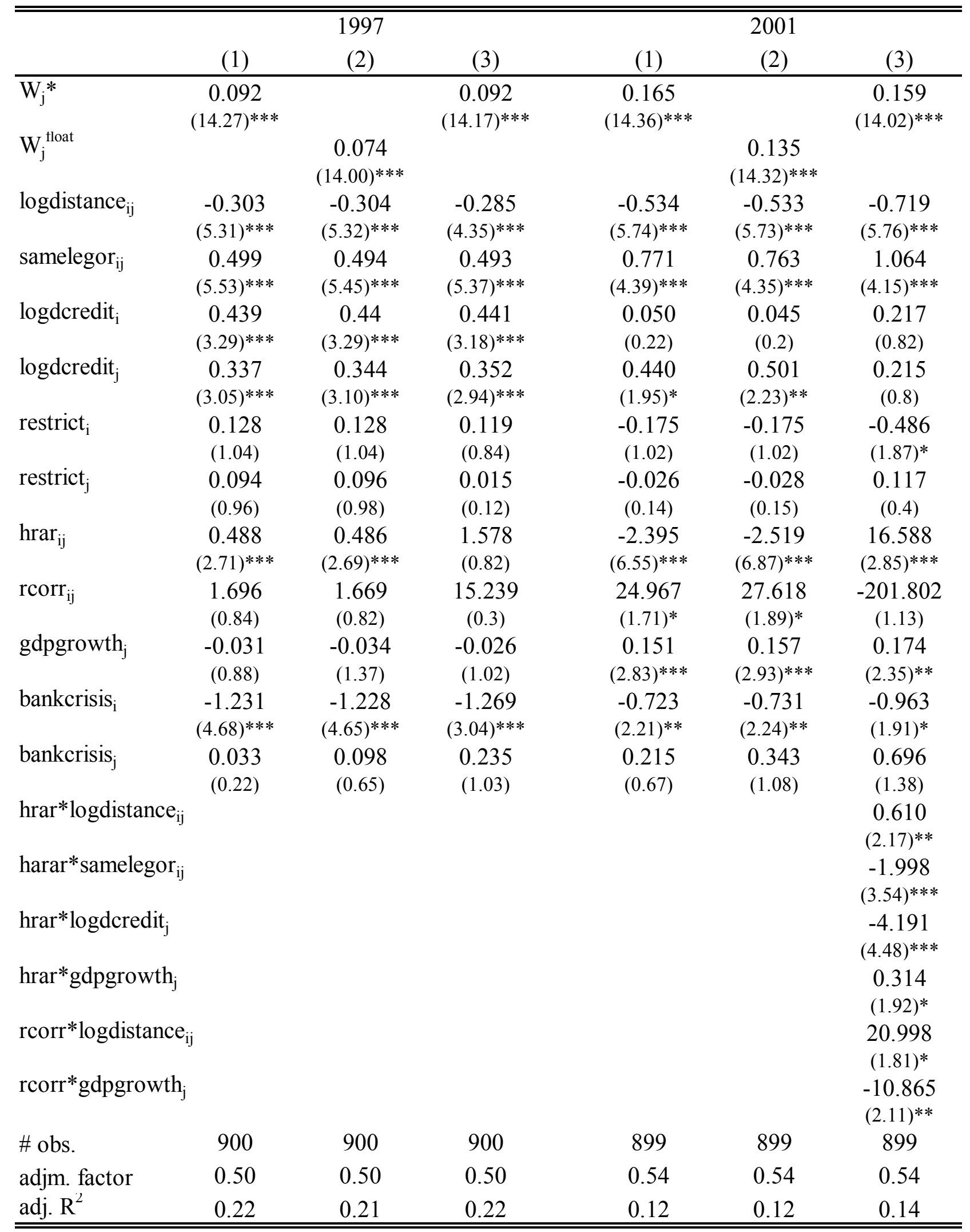

Notes: Dependent variable for all specifications: $\mathrm{W}_{\mathrm{ij}}{ }^{\text {act, }}$; Tobit estimation of a corner solution model. Absolute values of $t$ statistics are reported in parentheses. Region dummies for the country of origin and the country of destination as well as a constant are included but not reported. 
Table 7: World and Float Portfolio for Different Regions

\begin{tabular}{|c|c|c|c|c|c|}
\hline & $\begin{array}{c}1997 \\
(5) \\
\end{array}$ & $\begin{array}{c}2001 \\
(5) \\
\end{array}$ & & $\begin{array}{c}1997 \\
(6) \\
\end{array}$ & $\begin{array}{c}2001 \\
(6) \\
\end{array}$ \\
\hline $\mathrm{W}_{\mathrm{j}}^{*}$ & $\begin{array}{c}0.124 \\
(1171) * * *\end{array}$ & $\begin{array}{c}0.259 \\
(1585) * * *\end{array}$ & $\mathrm{~W}_{\mathrm{j}}^{\text {float }}$ & $\begin{array}{c}0.1 \\
(1137) * * *\end{array}$ & $\begin{array}{c}-0.52 \\
(6.58) * * *\end{array}$ \\
\hline$\left(\mathrm{W}_{\mathrm{j}}^{*}\right)^{*}$ samerica & $\begin{array}{l}-0.103 \\
(6.84)^{* * *}\end{array}$ & $\begin{array}{l}(15.85)^{* * *} \\
-0.200 \\
(9.06)^{* * *}\end{array}$ & $\mathrm{~W}_{\mathrm{j}}^{\text {tloat } *}$ samerica & $\begin{array}{l}-0.085 \\
(6.75)^{* * *}\end{array}$ & $\begin{array}{l}-0.166 \\
(9.00)^{* * *}\end{array}$ \\
\hline$\left(\mathrm{W}_{\mathrm{j}}^{*}\right) *$ namerica & $\begin{array}{c}0.050 \\
(2.36)^{* *}\end{array}$ & $\begin{array}{l}0.013 \\
(0.34)\end{array}$ & $\mathrm{W}_{\mathrm{j}}^{\text {tloat }} *$ namerica & $\begin{array}{c}0.045 \\
(2.51)^{* *}\end{array}$ & $\begin{array}{l}0.017 \\
(0.54)\end{array}$ \\
\hline$\left(\mathrm{W}_{\mathrm{j}}^{*}\right) *$ easia & $\begin{array}{l}-0.041 \\
(1.87)^{*}\end{array}$ & $\begin{array}{c}-0.182 \\
(7.15)^{* * *}\end{array}$ & $\mathrm{~W}_{\mathrm{j}}^{\text {float }} *$ easia & $\begin{array}{l}-0.033 \\
(1.79)^{*}\end{array}$ & $\begin{array}{c}-0.149 \\
(7.02)^{* * *}\end{array}$ \\
\hline$\left(\mathrm{W}_{\mathrm{j}}^{*}\right) *$ seasia & $\begin{array}{c}-0.102 \\
(7.05)^{* * * *}\end{array}$ & $\begin{array}{c}-0.191 \\
(8.14)^{* * *}\end{array}$ & $\mathrm{~W}_{\mathrm{j}}^{\text {tloat } * \text { seasia }}$ & $\begin{array}{c}-0.084 \\
(6.94) * * *\end{array}$ & $\begin{array}{c}-0.158 \\
(8.08)^{* * *}\end{array}$ \\
\hline$\left(\mathrm{W}_{\mathrm{j}}^{*}\right)^{*}$ wasia & $\begin{array}{c}-0.071 \\
(3.26)^{* * *}\end{array}$ & $\begin{array}{l}-0.179 \\
(5.73)^{* * *}\end{array}$ & $\mathrm{~W}_{\mathrm{j}}^{\text {float }} *$ wasia & $\begin{array}{c}-0.06 \\
(3.23)^{* * *}\end{array}$ & $\begin{array}{c}-0.147 \\
(5.69)^{* * *}\end{array}$ \\
\hline$\left(\mathrm{W}_{\mathrm{j}}^{*}\right)^{*}$ seurope & $\begin{array}{c}-0.060 \\
(4.09)^{* * * *}\end{array}$ & $\begin{array}{c}-0.173 \\
(7.48)^{* * *}\end{array}$ & $\mathrm{~W}_{\mathrm{j}}^{\text {float }} *$ seurope & $\begin{array}{c}-0.050 \\
(4.03)^{* * *}\end{array}$ & $\begin{array}{c}-0.143 \\
(7.42)^{* * *}\end{array}$ \\
\hline$\left(\mathrm{W}_{\mathrm{j}}^{*}\right) *$ neurope & $\begin{array}{c}0.026 \\
(2.07)^{* *}\end{array}$ & $\begin{array}{c}0.080 \\
(3.69) * * *\end{array}$ & $\mathrm{~W}_{\mathrm{j}}^{\text {tloat } * \text { neurope }}$ & $\begin{array}{c}0.022 \\
(2.07)^{* *}\end{array}$ & $\begin{array}{c}0.068 \\
(3.74)^{* * *}\end{array}$ \\
\hline$\left(\mathrm{W}_{\mathrm{j}}^{*}\right)^{*}$ oceania & $\begin{array}{c}-0.007 \\
(0.43)\end{array}$ & $\begin{array}{l}0.026 \\
(0.89)\end{array}$ & $\mathrm{W}_{\mathrm{j}}^{\text {tloat }} *$ oceania & $\begin{array}{l}-0.005 \\
(0.37)\end{array}$ & $\begin{array}{l}0.025 \\
(-1.00)\end{array}$ \\
\hline$\left(\mathrm{W}_{\mathrm{j}}^{*}\right) *$ eeurope & & $\begin{array}{c}-0.194 \\
(6.60)^{* * *}\end{array}$ & $\mathrm{~W}_{\mathrm{j}}^{\text {tloat }} *$ eeurope & & $\begin{array}{c}-0.161 \\
(6.60) * * *\end{array}$ \\
\hline$\left(\mathrm{W}_{\mathrm{j}}^{*}\right) *$ nafrica & & $\begin{array}{l}-0.190 \\
(4.64)^{* * *}\end{array}$ & $\mathrm{~W}_{\mathrm{j}}^{\text {tloat } * \text { nafrica }}$ & & $\begin{array}{c}-0.156 \\
(4.61)^{* * *}\end{array}$ \\
\hline $\operatorname{logdistance}_{i j}$ & $\begin{array}{l}-0.320 \\
(6.31)^{* * *}\end{array}$ & $\begin{array}{c}-0.520 \\
(6.58)^{* * *}\end{array}$ & $\operatorname{logdistance}_{\mathrm{ij}}$ & $\begin{array}{c}-0.319 \\
(6.26)^{* * *}\end{array}$ & $\begin{array}{c}-0.522 \\
(6.60)^{* * *}\end{array}$ \\
\hline samelegor $_{i j}$ & $\begin{array}{c}0.435 \\
(5.36)^{* * *}\end{array}$ & $\begin{array}{c}0.598 \\
(4.00)^{* * *}\end{array}$ & samelegor $_{\mathrm{ij}}$ & $\begin{array}{c}0.43 \\
(5.27)^{* * *}\end{array}$ & $\begin{array}{c}0.586 \\
(3.91)^{* * *}\end{array}$ \\
\hline $\operatorname{logdcredit}_{i}$ & $\begin{array}{c}0.412 \\
(3.52)^{* * *}\end{array}$ & $\begin{array}{l}-0.004 \\
(0.02)\end{array}$ & $\operatorname{logdcredit}_{i}$ & $\begin{array}{c}0.414 \\
(3.52)^{* * *}\end{array}$ & $\begin{array}{l}-0.012 \\
(0.06)\end{array}$ \\
\hline $\operatorname{logdcredit}_{\mathrm{j}}$ & $\begin{array}{c}0.311 \\
(3.19)^{* * *}\end{array}$ & $\begin{array}{l}0.338 \\
(1.79)^{*}\end{array}$ & $\operatorname{logdcredit}_{j}$ & $\begin{array}{c}0.316 \\
(3.23)^{* * *}\end{array}$ & $\begin{array}{c}0.408 \\
(2.16)^{* *}\end{array}$ \\
\hline restrict $_{\mathrm{i}}$ & $\begin{array}{c}0.073 \\
(0.7)\end{array}$ & $\begin{array}{l}-0.215 \\
(1.49)\end{array}$ & restrict $_{i}$ & $\begin{array}{l}0.077 \\
(0.73)\end{array}$ & $\begin{array}{c}-0.217 \\
(1.5)\end{array}$ \\
\hline restrict $_{j}$ & $\begin{array}{l}0.072 \\
(0.83)\end{array}$ & $\begin{array}{l}-0.004 \\
(0.03)\end{array}$ & restrict $_{j}$ & $\begin{array}{l}0.073 \\
(0.84)\end{array}$ & $\begin{array}{l}-0.007 \\
(0.04)\end{array}$ \\
\hline $\operatorname{hrar}_{\mathrm{ij}}$ & $\begin{array}{c}0.393 \\
(2.48)^{* *}\end{array}$ & $\begin{array}{c}-2.09 \\
(6.77)^{* * *}\end{array}$ & $\operatorname{hrar}_{\mathrm{ij}}$ & $\begin{array}{l}0.382 \\
(2.40)^{* *}\end{array}$ & $\begin{array}{l}-2.266 \\
(7.33)^{* * *}\end{array}$ \\
\hline $\operatorname{rcorr}_{i j}$ & $\begin{array}{c}-0.950 \\
(0.52)\end{array}$ & $\begin{array}{l}7.342 \\
(0.6)\end{array}$ & rcorr $_{i j}$ & $\begin{array}{l}-0.868 \\
(0.48)\end{array}$ & $\begin{array}{c}10.279 \\
(0.84)\end{array}$ \\
\hline gdpgrowth $_{\mathrm{j}}$ & $\begin{array}{l}-0.027 \\
(1.26)\end{array}$ & $\begin{array}{c}0.111 \\
(2.48)^{* *}\end{array}$ & gdpgrowth $_{\mathrm{j}}$ & $\begin{array}{l}-0.030 \\
(1.39)\end{array}$ & $\begin{array}{c}0.119 \\
(2.66)^{* * *}\end{array}$ \\
\hline bankcrisis $_{i}$ & $\begin{array}{c}-1.029 \\
(4.50)^{* * *}\end{array}$ & $\begin{array}{c}-0.728 \\
(2.66)^{* * *}\end{array}$ & bankcrisis $_{i}$ & $\begin{array}{c}-1.035 \\
(4.50)^{* * *}\end{array}$ & $\begin{array}{c}-0.73 \\
(2.66)^{* * *}\end{array}$ \\
\hline bankcrisis $_{j}$ & $\begin{array}{l}0.015 \\
(0.11)\end{array}$ & $\begin{array}{l}0.147 \\
(0.55)\end{array}$ & bankcrisis $_{\mathrm{j}}$ & $\begin{array}{l}0.084 \\
(0.64)\end{array}$ & $\begin{array}{l}0.284 \\
(1.06)\end{array}$ \\
\hline \# obs. & 900 & 899 & \# obs. & 900 & 899 \\
\hline adjm. factor & 0.5 & 0.55 & adjm. factor & 0.5 & 0.55 \\
\hline adj. $R^{2}$ & 0.27 & 0.19 & adj. $R^{2}$ & 0.27 & 0.19 \\
\hline
\end{tabular}


Table 8: World and Float Portfolio for the U.S. and Country Pairs of the EMU

\begin{tabular}{|c|c|c|c|c|c|}
\hline & $\begin{array}{c}1997 \\
(7) \\
\end{array}$ & $\begin{array}{c}2001 \\
(7) \\
\end{array}$ & & $\begin{array}{c}1997 \\
(8) \\
\end{array}$ & $\begin{array}{c}2001 \\
(8) \\
\end{array}$ \\
\hline$\overline{\mathrm{W}_{\mathrm{j}}^{*}}$ & $\begin{array}{c}0.092 \\
(14.24)^{* * * *}\end{array}$ & $\begin{array}{c}0.162 \\
(14.15)^{* * *}\end{array}$ & $\mathrm{~W}_{\mathrm{j}}^{\text {float }}$ & $\begin{array}{c}0.074 \\
(13.99)^{* * * *}\end{array}$ & $\begin{array}{c}0.133 \\
(14.15)^{* * *}\end{array}$ \\
\hline$\left(\mathrm{W}_{\mathrm{j}}^{*}\right) * \mathrm{U} . \mathrm{S}$. & $\begin{array}{c}-0.026 \\
(0.34)\end{array}$ & $\begin{array}{c}-0.162 \\
(0.97)\end{array}$ & $\mathrm{W}_{\mathrm{j}}^{\text {float }} *$ U.S. & $\begin{array}{c}-0.015 \\
(0.19)\end{array}$ & $\begin{array}{c}-0.133 \\
(0.77)\end{array}$ \\
\hline$\left(\mathrm{W}_{\mathrm{j}}^{*}\right)^{*} \mathrm{EMU}$ & $\begin{array}{l}0.094 \\
(1.16)\end{array}$ & $\begin{array}{c}0.283 \\
(2.31)^{* *}\end{array}$ & $\mathrm{~W}_{\mathrm{j}}^{\text {tloat }} * \mathrm{EMU}$ & $\begin{array}{l}0.137 \\
(-1.30)\end{array}$ & $\begin{array}{c}0.391 \\
(2.48)^{* *}\end{array}$ \\
\hline $\operatorname{logdistance}_{\mathrm{ij}}$ & $\begin{array}{c}-0.288 \\
(4.94)^{* * *}\end{array}$ & $\begin{array}{c}-0.493 \\
(5.23)^{* * *}\end{array}$ & $\operatorname{logdistance}_{\mathrm{ij}}$ & $\begin{array}{c}-0.287 \\
(4.91)^{* * *}\end{array}$ & $\begin{array}{c}-0.488 \\
(5.18)^{* * *}\end{array}$ \\
\hline samelegor $_{\mathrm{ij}}$ & $\begin{array}{c}0.492 \\
(5.44)^{* * *}\end{array}$ & $\begin{array}{c}0.744 \\
(4.25)^{* * * *}\end{array}$ & samelegor $_{\mathrm{ij}}$ & $\begin{array}{c}0.485 \\
(5.33)^{* * *}\end{array}$ & $\begin{array}{c}0.733 \\
(4.18)^{* * *}\end{array}$ \\
\hline $\operatorname{logdcredit}_{i}$ & $\begin{array}{c}0.445 \\
(3.33)^{* * *}\end{array}$ & $\begin{array}{l}0.094 \\
(0.41)\end{array}$ & $\operatorname{logdcredit}_{i}$ & $\begin{array}{c}0.444 \\
(3.32)^{* * *}\end{array}$ & $\begin{array}{l}0.085 \\
(0.37)\end{array}$ \\
\hline $\operatorname{logdcredit}_{j}$ & $\begin{array}{c}0.341 \\
(3.08)^{* * *}\end{array}$ & $\begin{array}{c}0.457 \\
(2.03)^{* *}\end{array}$ & $\operatorname{logdcredit}_{j}$ & $\begin{array}{c}0.347 \\
(3.13)^{* * *}\end{array}$ & $\begin{array}{c}0.517 \\
(2.31)^{* *}\end{array}$ \\
\hline restrict $_{i}$ & $\begin{array}{l}0.125 \\
(1.03)\end{array}$ & $\begin{array}{l}-0.183 \\
(1.07)\end{array}$ & restrict $_{\mathrm{i}}$ & $\begin{array}{l}0.126 \\
(1.03)\end{array}$ & $\begin{array}{l}-0.184 \\
(1.07)\end{array}$ \\
\hline restrict $_{j}$ & $\begin{array}{c}0.09 \\
(0.92)\end{array}$ & $\begin{array}{c}-0.011 \\
(0.06)\end{array}$ & restrict $_{j}$ & $\begin{array}{l}0.092 \\
(0.94)\end{array}$ & $\begin{array}{c}-0.011 \\
(0.06)\end{array}$ \\
\hline $\operatorname{hrar}_{\mathrm{ij}}$ & $\begin{array}{c}0.472 \\
(2.62)^{* * *}\end{array}$ & $\begin{array}{c}-2.273 \\
(6.12)^{* * *}\end{array}$ & $\operatorname{hrar}_{\mathrm{ij}}$ & $\begin{array}{c}0.469 \\
(2.59)^{* * *}\end{array}$ & $\begin{array}{c}-2.371 \\
(6.37)^{* * *}\end{array}$ \\
\hline $\operatorname{rcorr}_{i j}$ & $\begin{array}{l}1.813 \\
(0.89)\end{array}$ & $\begin{array}{c}20.792 \\
(1.42)\end{array}$ & $\operatorname{rcorr}_{\mathrm{ij}}$ & $\begin{array}{c}1.79 \\
(0.88)\end{array}$ & $\begin{array}{c}23.011 \\
(1.57)\end{array}$ \\
\hline gdpgrowth $_{\mathrm{j}}$ & $\begin{array}{l}-0.031 \\
(1.24)\end{array}$ & $\begin{array}{c}0.138 \\
(2.59)^{* * *}\end{array}$ & gdpgrowth $_{\mathrm{ij}}$ & $\begin{array}{l}-0.034 \\
(1.35)\end{array}$ & $\begin{array}{c}0.142 \\
(2.66)^{* * *}\end{array}$ \\
\hline bankcrisis $_{i}$ & $\begin{array}{c}-1.227 \\
(4.67)^{* * *}\end{array}$ & $\begin{array}{l}-0.694 \\
(2.13)^{* *}\end{array}$ & bankcrisis $_{i}$ & $\begin{array}{c}-1.224 \\
(4.65)^{* * *}\end{array}$ & $\begin{array}{l}-0.703 \\
(2.16)^{* *}\end{array}$ \\
\hline bankcrisis $_{j}$ & $\begin{array}{l}0.034 \\
(0.23)\end{array}$ & $\begin{array}{l}0.221 \\
(0.69)\end{array}$ & bankcrisis $_{j}$ & $\begin{array}{l}0.084 \\
(0.65)\end{array}$ & $\begin{array}{l}0.341 \\
(1.08)\end{array}$ \\
\hline \# obs. & 900 & 899 & \# obs. & 900 & 899 \\
\hline $\begin{array}{l}\text { adjm. factor } \\
\text { adj. } R^{2}\end{array}$ & $\begin{array}{c}0.5 \\
0.22\end{array}$ & $\begin{array}{l}0.54 \\
0.13\end{array}$ & $\begin{array}{l}\text { adjm. factor } \\
\text { adj. } \mathrm{R}^{2}\end{array}$ & $\begin{array}{c}0.5 \\
0.22\end{array}$ & $\begin{array}{l}0.54 \\
0.13\end{array}$ \\
\hline
\end{tabular}

Notes: see Table 7. 
Table 9: Basic Regression Results for Within-EMU Investments Only

\begin{tabular}{|c|c|c|c|c|}
\hline & $\begin{array}{c}1997 \\
(1)\end{array}$ & $\begin{array}{c}1997 \\
(2)\end{array}$ & $\begin{array}{c}2001 \\
(1)\end{array}$ & $\begin{array}{c}2001 \\
(2)\end{array}$ \\
\hline$\overline{\mathrm{W}_{\mathrm{j}}^{*}}$ & $\begin{array}{c}0.363 \\
(5.27)^{* * *}\end{array}$ & & $\begin{array}{c}0.728 \\
(5.42)^{* * *}\end{array}$ & \\
\hline $\mathrm{W}_{\mathrm{j}}^{\text {float }}$ & & $\begin{array}{c}0.471 \\
(5.29)^{* * *}\end{array}$ & & $\begin{array}{c}0.951 \\
(5.53)^{* * *}\end{array}$ \\
\hline $\operatorname{logdistance}_{\mathrm{ij}}$ & $\begin{array}{l}-0.317 \\
(2.41)^{* *}\end{array}$ & $\begin{array}{l}-0.324 \\
(2.47)^{* *}\end{array}$ & $\begin{array}{c}-1.439 \\
(4.91)^{* * *}\end{array}$ & $\begin{array}{c}-1.441 \\
(4.95)^{* * *}\end{array}$ \\
\hline samelegor $_{\mathrm{ij}}$ & $\begin{array}{l}0.11 \\
(0.73)\end{array}$ & $\begin{array}{l}0.09 \\
(0.6)\end{array}$ & $\begin{array}{l}0.449 \\
(1.32)\end{array}$ & $\begin{array}{l}0.44 \\
(1.3)\end{array}$ \\
\hline $\operatorname{logdcredit}_{\mathrm{i}}$ & $\begin{array}{l}0.077 \\
(0.23)\end{array}$ & $\begin{array}{l}0.091 \\
(0.27)\end{array}$ & $\begin{array}{l}-1.135 \\
(1.84)^{*}\end{array}$ & $\begin{array}{l}-1.141 \\
(1.86)^{*}\end{array}$ \\
\hline $\operatorname{logdcredit}_{j}$ & $\begin{array}{c}0.669 \\
(1.97)^{*}\end{array}$ & $\begin{array}{c}0.713 \\
(2.11)^{* *}\end{array}$ & $\begin{array}{l}0.239 \\
(0.39)\end{array}$ & $\begin{array}{l}0.261 \\
(0.43)\end{array}$ \\
\hline $\operatorname{hrar}_{\mathrm{ij}}$ & $\begin{array}{c}0.731 \\
(3.56)^{* * *}\end{array}$ & $\begin{array}{c}0.718 \\
(3.50)^{* * *}\end{array}$ & $\begin{array}{c}-2.159 \\
(3.76)^{* * *}\end{array}$ & $\begin{array}{c}-2.159 \\
(3.78)^{* * *}\end{array}$ \\
\hline $\operatorname{rcorr}_{\mathrm{ij}}$ & $\begin{array}{c}-20.131 \\
(0.72)\end{array}$ & $\begin{array}{c}-19.867 \\
(0.71)\end{array}$ & $\begin{array}{l}-88.836 \\
(2.20)^{* *}\end{array}$ & $\begin{array}{l}-87.588 \\
(2.18)^{* *}\end{array}$ \\
\hline gdpgrowth $_{\mathrm{j}}$ & $\begin{array}{c}-0.018 \\
(0.37)\end{array}$ & $\begin{array}{c}-0.026 \\
(0.55)\end{array}$ & $\begin{array}{l}0.191 \\
(1.59)\end{array}$ & $\begin{array}{l}0.193 \\
(1.61)\end{array}$ \\
\hline \# obs. & 81 & 81 & 108 & 108 \\
\hline adj. factor & 0.73 & 0.73 & 0.7 & 0.7 \\
\hline adj. $R^{2}$ & 0.31 & 0.31 & 0.16 & 0.16 \\
\hline LR-Test: $W^{*}=1$ & 0.00 & 0.00 & 0.05 & 0.77 \\
\hline
\end{tabular}

Notes: Dependent variable for all specifications: $\mathrm{W}_{\mathrm{ij}}{ }^{\text {act, }}$; Tobit estimation of a corner solution model. Absolute values of $t$ statistics are reported in parentheses. A constant are included but not reported. 


\section{Appendix}

\section{A Calculation of Optimal and Actual Portfolio Shares}

The actual portfolio share, $W_{i j, t}^{a c t}$, can be calculated as foreign equity holdings of country $i$ in country $j, e q u a_{i j, t}$, relative to country $i$ 's total holdings of foreign as well as domestic equities, equa $a_{i, t}^{\text {tot }}=\sum_{i=1}^{N} e q u a_{i j, t}$ :

$$
W_{i j, t}^{a c t}=\frac{e q u a_{i j, t}}{e q u a_{i, t}^{t t t}}
$$

As equatit is not directly available from the CPIS data, ${ }^{40}$ country $i$ 's total equity holdings are calculated as follows:

$$
e q u a_{i, t}^{t o t}=M C A P_{i, t}-\sum_{j=1, j \neq i}^{N} e q u a_{j i, t}+\sum_{i=1, i \neq j}^{N} e q u a_{i j, t}
$$

where $\sum_{j=1, j \neq i}^{N} e q u a_{j i, t}$ denotes all foreign assets of country $i$ held in the rest of the world and $\sum_{i=1, i \neq j}^{N} e q u a_{i j, t}$ the sum of all equity assets of the rest of the world held in country $i$.

\section{B Robustness Checks}

Additional estimates employing different econometric techniques and using alternative proxies for frictions are undertaken in order to underline the robustness of the results presented in Section 5.

Specifications (1) and (2) are estimated with OLS for positive values given the data problems of reported zero investments for 1997 (see Section 4). Regression results in Table 11, first two columns, show that for positive foreign portfolio shares estimated coefficients look very much like the ones in the Tobit model except for interaction effects. Results are stable towards the choice of estimation methods. Partial effects, however, are different and nonlinear in the Tobit model and on average only half as large as in the OLS case. The Tobit model is preferred because nonlinearities are very likely for small foreign portfolio shares.

\footnotetext{
${ }^{40}$ The data includes only foreign equity securities and no domestic securities, equa $a_{i, t}$.
} 
In order to further investigate the sensitivity of the results with respect to the reported zero problem for the 1997 sample, an alternative sample is estimated for 1997 where a missing value is imputed for a zero entry whenever a missing is present for 2001. Descriptive statistics for this sample are summarized in Table 10. Compared to the sample employed before, the average value of actual foreign portfolio shares is larger due to a larger number of missing values instead of zeros. Regression results for specifications (1) and (2), (Table 11, last two columns) are not very sensitive towards these changes in the sample. Coefficients are very close to the ones described in Section 5.

In Tables 12 and 13 several proxies of capital market frictions are exchanged by others in order to test the validity of the proxies. First, in specification (9) a dummy variable equal to one if both countries share the same language or colonial background, language laj,t $_{\text {, }}$ is used instead of the dummy variable for both countries sharing the same legal origin. Both variables proxy information advantages (see Section 2.1). Second, instead of logdistance $_{i j, t}$ a dummy variable for both countries sharing a common border, adjacency $y_{i j, t}$, is used in specification (10) in order to proxy information advantages due to proximity. Third, as a further alternative measure for distance a dummy variable equal to one if a country pair is part of the same region is employed [specification (11)]. Again the regional subdivision of Table 3 applies. Fourth, it is argued in the paper that financial market development proxied by logdcredit $t_{i, t}$ is likely to have a positive impact on foreign portfolio shares. However, the effect might also be opposite: Too much bank financing at home may indicate an unsatisfied demand for listed stocks that is resolved by going abroad. This issue is considered by controlling for the size of the home stock market adding the ratio of market capitalization in the home country relative to GDP, mcap $/ G D P_{i, t}$, as an explaining variable [specification (12)]. Regression results of specifications (9) to (12) demonstrate that the proxies used for the main regressions are very robust: Significance levels do not change and the size of coefficients is very stable. The effect of logdcredit ${ }_{i, t}$ is not influenced by controlling for the size of the home stock market, mcap/GDP $P_{i, t}$.

Finally, different subsamples excluding major financial centers are estimated in order to check whether these have a strong impact on the size of the coefficients (Tables 14 and 15). When observations of EMU country pairs are excluded from the sample, almost the same coefficients as in the complete sample regressions are obtained except for some minor changes in magnitude. Similarly, results are stable but coefficients are slightly smaller when the U.S. is excluded from the sample. This can also be observed when the U.K. is not part of the sample. Coefficients are even less affected if Japan is excluded. Overall, the exclusion of important financial centers leads to only marginally different results. 
Table 10: Descriptive Statistics

\begin{tabular}{lccccc}
\hline \hline & & \multicolumn{5}{c}{1997} \\
Variable & Obs. & Mean & Std. Dev. & Min & Max \\
\hline $\mathrm{W}_{\mathrm{ij}}{ }^{\text {act }}$ & 795 & 0.41 & 1.32 & 0.00 & 18.86 \\
$\mathrm{~W}_{\mathrm{j}}{ }^{\mathrm{f}}$ & 795 & 2.79 & 8.38 & 0.05 & 48.63 \\
$\mathrm{~W}_{\mathrm{j}}^{\text {float }}$ & 795 & 2.89 & 10.01 & 0.02 & 58.32 \\
logdistance $_{\mathrm{ij}}$ & 795 & 8.50 & 1.08 & 5.16 & 9.90 \\
adjacency $_{\mathrm{ij}}$ & 795 & 0.05 & 0.22 & 0.00 & 1.00 \\
samelegor $_{\mathrm{ij}}$ & 795 & 0.28 & 0.45 & 0.00 & 1.00 \\
language $_{\mathrm{ij}}$ & 795 & 0.15 & 0.36 & 0.00 & 1.00 \\
logdcredit $_{\mathrm{i}}$ & 795 & 4.42 & 0.50 & 2.66 & 5.26 \\
logdcredit $_{\mathrm{j}}$ & 795 & 4.28 & 0.65 & 2.66 & 5.26 \\
restrict $_{\mathrm{i}}$ & 795 & 0.27 & 0.71 & 0.00 & 3.00 \\
restrict $_{\mathrm{j}}$ & 795 & 0.56 & 0.93 & 0.00 & 3.00 \\
hrar $_{\mathrm{ij}}$ & 795 & 0.02 & 0.46 & -1.79 & 1.79 \\
rcorr $_{\mathrm{ij}}$ & 795 & 0.00 & 0.02 & -0.05 & 0.21 \\
gdpgrowth $_{\mathrm{j}}$ & 795 & 1.39 & 2.39 & -7.39 & 8.54 \\
bankcrisis $_{\mathrm{i}}$ & 795 & 0.13 & 0.33 & 0.00 & 1.00 \\
bankcrisis $_{\mathrm{j}}$ & 795 & 0.14 & 0.35 & 0.00 & 1.00 \\
\hline \hline
\end{tabular}

Note: $\mathrm{W}_{\mathrm{ij}}{ }^{\text {act }}$ and $\mathrm{W}_{\mathrm{j}}{ }^{*}$ are measured in percent. 
Table 11: Basic Regression Results, Robustness Checks

\begin{tabular}{|c|c|c|c|c|c|c|}
\hline & $\begin{array}{c}1997 \\
(1)\end{array}$ & $\begin{array}{c}1997 \\
(2) \\
\end{array}$ & $\begin{array}{c}2001 \\
(1)\end{array}$ & $\begin{array}{c}2001 \\
(2)\end{array}$ & $\begin{array}{c}1997 \\
(1)\end{array}$ & $\begin{array}{c}1997 \\
(2) \\
\end{array}$ \\
\hline $\mathrm{W}_{\mathrm{j}}^{*}$ & $\begin{array}{c}0.094 \\
(5.48)^{* * *}\end{array}$ & & $\begin{array}{c}0.155 \\
(5.48)^{* * *}\end{array}$ & & $\begin{array}{c}0.095 \\
(14.52)^{* * * *}\end{array}$ & \\
\hline $\mathrm{W}_{\mathrm{j}}^{\text {float }}$ & & $\begin{array}{c}0.076 \\
(5.38)^{* * *}\end{array}$ & & $\begin{array}{c}0.127 \\
(5.40)^{* * *}\end{array}$ & & $\begin{array}{c}0.077 \\
(14.26)^{* * *}\end{array}$ \\
\hline $\operatorname{logdistance}_{\mathrm{ij}}$ & $\begin{array}{c}-0.261 \\
(3.27)^{* * *}\end{array}$ & $\begin{array}{c}-0.262 \\
(3.27)^{* * *}\end{array}$ & $\begin{array}{c}-0.474 \\
(4.63)^{* * *}\end{array}$ & $\begin{array}{c}-0.473 \\
(4.62)^{* * *}\end{array}$ & $\begin{array}{c}-0.293 \\
(5.03)^{* * *}\end{array}$ & $\begin{array}{c}-0.294 \\
(5.04)^{* * *}\end{array}$ \\
\hline samelegor $_{i j}$ & $\begin{array}{c}0.434 \\
(2.89)^{* * *}\end{array}$ & $\begin{array}{c}0.427 \\
(2.85)^{* * *}\end{array}$ & $\begin{array}{c}0.773 \\
(2.62)^{* * * *}\end{array}$ & $\begin{array}{c}0.767 \\
(2.60)^{* * *}\end{array}$ & $\begin{array}{c}0.484 \\
(5.23)^{* * *}\end{array}$ & $\begin{array}{c}0.479 \\
(5.15)^{* * *}\end{array}$ \\
\hline $\operatorname{logdcredit}_{\mathrm{i}}$ & $\begin{array}{c}0.216 \\
(2.06)^{* *}\end{array}$ & $\begin{array}{c}0.216 \\
(2.04)^{* *}\end{array}$ & $\begin{array}{l}0.062 \\
(0.32)\end{array}$ & $\begin{array}{l}0.058 \\
(0.30)\end{array}$ & $\begin{array}{l}0.232 \\
(1.63)\end{array}$ & $\begin{array}{l}0.232 \\
(1.62)\end{array}$ \\
\hline $\operatorname{logdcredit}_{j}$ & $\begin{array}{c}0.306 \\
(3.13)^{* * *}\end{array}$ & $\begin{array}{c}0.313 \\
(3.17)^{* * *}\end{array}$ & $\begin{array}{c}0.446 \\
(3.04)^{* * * *}\end{array}$ & $\begin{array}{c}0.503 \\
(3.41)^{* * *}\end{array}$ & $\begin{array}{c}0.305 \\
(2.69)^{* * *}\end{array}$ & $\begin{array}{c}0.312 \\
(2.73)^{* * *}\end{array}$ \\
\hline restrict $_{i}$ & $\begin{array}{l}0.013 \\
(0.08)\end{array}$ & $\begin{array}{l}0.011 \\
(0.08)\end{array}$ & $\begin{array}{c}-0.211 \\
(1.49)\end{array}$ & $\begin{array}{c}-0.212 \\
(1.49)\end{array}$ & $\begin{array}{l}0.196 \\
(1.59)\end{array}$ & $\begin{array}{l}0.196 \\
(1.59)\end{array}$ \\
\hline restrict $_{j}$ & $\begin{array}{l}0.059 \\
(1.27)\end{array}$ & $\begin{array}{l}0.06 \\
(1.28)\end{array}$ & $\begin{array}{l}0.038 \\
(0.52)\end{array}$ & $\begin{array}{l}0.035 \\
(0.48)\end{array}$ & $\begin{array}{l}0.063 \\
(0.62)\end{array}$ & $\begin{array}{l}0.064 \\
(0.63)\end{array}$ \\
\hline $\operatorname{hrar}_{\mathrm{ij}}$ & $\begin{array}{c}0.399 \\
(2.49)^{* *}\end{array}$ & $\begin{array}{c}0.399 \\
(2.45)^{* *}\end{array}$ & $\begin{array}{c}-2.512 \\
(3.89)^{* * *}\end{array}$ & $\begin{array}{c}-2.629 \\
(3.99)^{* * *}\end{array}$ & $\begin{array}{l}0.322 \\
(1.73)^{*}\end{array}$ & $\begin{array}{c}0.32 \\
(1.71)^{*}\end{array}$ \\
\hline rcorr $_{\mathrm{ij}}$ & $\begin{array}{l}1.467 \\
(0.72)\end{array}$ & $\begin{array}{c}1.437 \\
(0.7)\end{array}$ & $\begin{array}{l}18.891 \\
(2.04)^{* *}\end{array}$ & $\begin{array}{l}21.573 \\
(2.32)^{* *}\end{array}$ & $\begin{array}{l}1.156 \\
(0.53)\end{array}$ & $\begin{array}{l}1.114 \\
(0.51)\end{array}$ \\
\hline gdpgrowth $_{j}$ & $\begin{array}{l}-0.026 \\
(2.12)^{* *}\end{array}$ & $\begin{array}{l}-0.731 \\
(2.43)^{* *}\end{array}$ & $\begin{array}{c}0.133 \\
(4.46)^{* * *}\end{array}$ & $\begin{array}{c}0.139 \\
(4.55)^{* * *}\end{array}$ & $\begin{array}{c}-0.023 \\
(0.89)\end{array}$ & $\begin{array}{c}-0.026 \\
(1.01)\end{array}$ \\
\hline bankcrisis $_{i}$ & $\begin{array}{l}-0.739 \\
(2.44)^{* *}\end{array}$ & $\begin{array}{l}-0.731 \\
(2.43)^{* *}\end{array}$ & $\begin{array}{c}-0.272 \\
(1.1)\end{array}$ & $\begin{array}{c}-0.275 \\
(1.11)\end{array}$ & $\begin{array}{c}-1.153 \\
(4.21)^{* * *}\end{array}$ & $\begin{array}{c}-1.149 \\
(4.18)^{* * *}\end{array}$ \\
\hline bankcrisis $_{\mathrm{j}}$ & $\begin{array}{l}0.038 \\
(0.48)\end{array}$ & $\begin{array}{l}0.104 \\
(1.32)\end{array}$ & $\begin{array}{l}0.295 \\
(1.77)^{*}\end{array}$ & $\begin{array}{c}0.417 \\
(2.53)^{* *}\end{array}$ & $\begin{array}{l}0.043 \\
(0.28)\end{array}$ & $\begin{array}{c}0.11 \\
(0.72)\end{array}$ \\
\hline \# obs. & 707 & 707 & 796 & 796 & 795 & 795 \\
\hline $\begin{array}{l}\text { adj. } R^{2} \\
\text { adjm. factor }\end{array}$ & 0.42 & 0.42 & 0.4 & 0.4 & $\begin{array}{l}0.56 \\
0.19\end{array}$ & $\begin{array}{l}0.56 \\
0.18\end{array}$ \\
\hline
\end{tabular}

Note: Dependent variable for all specifications: $\mathrm{W}_{\mathrm{ij}}{ }^{\text {act }}$; The first four columns refer to OLS estimations of positive foreign portfolio shares. The last two columns refer to Tobit estimations of a corner solution model for an alternative sample (see Section 4 and 5). Absolute values of $t$ statistics are reported in parentheses. Region dummies for the country of origin and the country of destination as well as a constant are included but not reported. 
Table 12: Basic Regression Results, Robustness Checks

\begin{tabular}{|c|c|c|c|c|}
\hline & $\begin{array}{c}1997 \\
(9) \\
\end{array}$ & $\begin{array}{c}2001 \\
(9) \\
\end{array}$ & $\begin{array}{l}1997 \\
(10)\end{array}$ & $\begin{array}{r}2001 \\
(10) \\
\end{array}$ \\
\hline $\mathrm{W}_{\mathrm{j}}{ }^{*}$ & $\begin{array}{c}0.093 \\
(14.52)^{* * *}\end{array}$ & $\begin{array}{c}0.166 \\
(14.46)^{* * *}\end{array}$ & $\begin{array}{c}0.093 \\
(14.50)^{* * *}\end{array}$ & $\begin{array}{c}0.164 \\
(14.30)^{* * *}\end{array}$ \\
\hline $\operatorname{logdistance}_{\mathrm{ij}}$ & $\begin{array}{c}-0.294 \\
(5.20)^{* * *}\end{array}$ & $\begin{array}{c}-0.517 \\
(5.54)^{* * *}\end{array}$ & & \\
\hline $\operatorname{adjacency}_{\mathrm{ij}}$ & & & $\begin{array}{c}1.143 \\
(6.26)^{* * *}\end{array}$ & $\begin{array}{c}1.908 \\
(5.57)^{* * *}\end{array}$ \\
\hline samelegor $_{i j}$ & & & $\begin{array}{c}0.454 \\
(5.02)^{* * *}\end{array}$ & $\begin{array}{c}0.73 \\
(4.12)^{* * *}\end{array}$ \\
\hline language $_{\mathrm{ij}}$ & $\begin{array}{c}0.776 \\
(6.46)^{* * *}\end{array}$ & $\begin{array}{c}1.078 \\
(4.68)^{* * *}\end{array}$ & & \\
\hline $\operatorname{logdcredit}_{i}$ & $\begin{array}{c}0.375 \\
(2.81)^{* * *}\end{array}$ & $\begin{array}{c}0.00 \\
(0.00)\end{array}$ & $\begin{array}{c}0.430 \\
(3.26)^{* * *}\end{array}$ & $\begin{array}{c}-0.060 \\
(0.26)\end{array}$ \\
\hline $\operatorname{logdcredit}_{\mathrm{j}}$ & $\begin{array}{c}0.262 \\
(2.37)^{* *}\end{array}$ & $\begin{array}{l}0.407 \\
(1.80)^{*}\end{array}$ & $\begin{array}{c}0.289 \\
(2.64)^{* * *}\end{array}$ & $\begin{array}{c}0.449 \\
(1.99)^{* *}\end{array}$ \\
\hline restrict $_{i}$ & $\begin{array}{l}0.176 \\
(1.42)\end{array}$ & $\begin{array}{c}-0.140 \\
(0.81)\end{array}$ & $\begin{array}{l}0.132 \\
(1.09)\end{array}$ & $\begin{array}{c}-0.137 \\
(0.8)\end{array}$ \\
\hline restrict $_{j}$ & $\begin{array}{l}0.094 \\
(0.96)\end{array}$ & $\begin{array}{l}0.006 \\
(0.03)\end{array}$ & $\begin{array}{l}0.086 \\
(0.88)\end{array}$ & $\begin{array}{c}0.01 \\
(0.05)\end{array}$ \\
\hline $\operatorname{hrar}_{\mathrm{ij}}$ & $\begin{array}{c}0.456 \\
(2.55)^{* *}\end{array}$ & $\begin{array}{c}-2.364 \\
(6.47)^{* * *}\end{array}$ & $\begin{array}{c}0.446 \\
(2.50)^{* *}\end{array}$ & $\begin{array}{c}-2.384 \\
(6.53)^{* * *}\end{array}$ \\
\hline rcorr $_{\mathrm{ij}}$ & $\begin{array}{l}2.046 \\
(1.01)\end{array}$ & $\begin{array}{l}25.007 \\
(1.72)^{*}\end{array}$ & $\begin{array}{l}4.187 \\
(2.34)^{* *}\end{array}$ & $\begin{array}{c}22.282 \\
(1.53)\end{array}$ \\
\hline gdpgrowth $_{\mathrm{j}}$ & $\begin{array}{c}-0.039 \\
(1.59)\end{array}$ & $\begin{array}{c}0.14 \\
(2.63)^{* * *}\end{array}$ & $\begin{array}{c}-0.024 \\
(0.99)\end{array}$ & $\begin{array}{c}0.142 \\
(2.68)^{* * *}\end{array}$ \\
\hline bankcrisis $_{i}$ & $\begin{array}{c}-1.086 \\
(4.14)^{* * *}\end{array}$ & $\begin{array}{l}-0.615 \\
(1.87)^{*}\end{array}$ & $\begin{array}{c}-1.268 \\
(4.88)^{* * *}\end{array}$ & $\begin{array}{c}-0.857 \\
(2.62)^{* * *}\end{array}$ \\
\hline bankcrisis $_{j}$ & $\begin{array}{l}0.200 \\
(1.32)\end{array}$ & $\begin{array}{l}0.304 \\
(0.95)\end{array}$ & $\begin{array}{c}-0.012 \\
(0.08)\end{array}$ & $\begin{array}{l}0.170 \\
(0.53)\end{array}$ \\
\hline \# obs. & 900 & 899 & 900 & 899 \\
\hline adjm. factor & 0.5 & 0.54 & 0.5 & 0.54 \\
\hline $\operatorname{adj} . R^{2}$ & 0.22 & 0.12 & 0.22 & 0.12 \\
\hline
\end{tabular}

Notes: see Table 7. 
Table 13: Basic Regression Results, Robustness Checks

\begin{tabular}{|c|c|c|c|c|}
\hline & $\begin{array}{l}1997 \\
(11)\end{array}$ & $\begin{array}{l}2001 \\
(11)\end{array}$ & $\begin{array}{l}1997 \\
(12)\end{array}$ & $\begin{array}{r}2001 \\
(12)\end{array}$ \\
\hline $\mathrm{W}_{\mathrm{j}}^{*}$ & $\begin{array}{c}0.092 \\
(14.14)^{* * *}\end{array}$ & $\begin{array}{c}0.164 \\
(14.18)^{* * *}\end{array}$ & $\begin{array}{c}0.092 \\
(14.25)^{* * *}\end{array}$ & $\begin{array}{c}0.164 \\
(14.40)^{* * *}\end{array}$ \\
\hline $\operatorname{logdistance} e_{i j}$ & & & $\begin{array}{c}-0.302 \\
(5.30)^{* * *}\end{array}$ & $\begin{array}{c}-0.538 \\
(5.81)^{* * *}\end{array}$ \\
\hline sameregion $_{\mathrm{ij}}$ & $\begin{array}{c}0.619 \\
(3.95)^{* * *}\end{array}$ & $\begin{array}{c}1.063 \\
(3.66)^{* * *}\end{array}$ & & \\
\hline samelegor $_{i j}$ & $\begin{array}{c}0.547 \\
(6.07)^{* * *}\end{array}$ & $\begin{array}{c}0.866 \\
(4.91)^{* * *}\end{array}$ & $\begin{array}{c}0.498 \\
(5.50)^{* * *}\end{array}$ & $\begin{array}{c}0.796 \\
(4.55)^{* * *}\end{array}$ \\
\hline $\operatorname{logdcredit}_{i}$ & $\begin{array}{c}0.425 \\
(3.17)^{* * *}\end{array}$ & $\begin{array}{l}0.007 \\
(0.03)\end{array}$ & $\begin{array}{c}0.392 \\
(2.50)^{* *}\end{array}$ & $\begin{array}{c}0.229 \\
-0.95\end{array}$ \\
\hline mcap/GDP & & & $\begin{array}{c}0.087 \\
(0.56)\end{array}$ & $\begin{array}{l}-0.406 \\
(2.55)^{* *}\end{array}$ \\
\hline $\operatorname{logdcredit}_{j}$ & $\begin{array}{c}0.341 \\
(3.06)^{* * *}\end{array}$ & $\begin{array}{c}0.455 \\
(2.00)^{* *}\end{array}$ & $\begin{array}{c}0.339 \\
(3.06)^{* * *}\end{array}$ & $\begin{array}{c}0.458 \\
(2.04)^{* *}\end{array}$ \\
\hline restrict $_{i}$ & $\begin{array}{l}0.126 \\
(1.02)\end{array}$ & $\begin{array}{c}-0.154 \\
(0.88)\end{array}$ & $\begin{array}{l}0.114 \\
(0.91)\end{array}$ & $\begin{array}{l}-0.195 \\
(1.13)\end{array}$ \\
\hline restrict $_{j}$ & $\begin{array}{l}0.092 \\
(0.93)\end{array}$ & $\begin{array}{l}-0.01 \\
(0.06)\end{array}$ & $\begin{array}{l}0.100 \\
(1.01)\end{array}$ & $\begin{array}{c}-0.022 \\
(0.12)\end{array}$ \\
\hline $\operatorname{hrar}_{\mathrm{ij}}$ & $\begin{array}{c}0.498 \\
(2.75)^{* * *}\end{array}$ & $\begin{array}{c}-2.369 \\
(6.41)^{* * *}\end{array}$ & $\begin{array}{c}0.516 \\
(2.76)^{* * *}\end{array}$ & $\begin{array}{c}-2.287 \\
(6.24)^{* * *}\end{array}$ \\
\hline rcorr $_{\mathrm{ij}}$ & $\begin{array}{c}4.253 \\
(2.25)^{* *}\end{array}$ & $\begin{array}{c}22.654 \\
(1.54)\end{array}$ & $\begin{array}{l}1.726 \\
(0.85)\end{array}$ & $\begin{array}{c}32.82 \\
(2.21)^{* *}\end{array}$ \\
\hline gdpgrowth $_{\mathrm{j}}$ & $\begin{array}{c}-0.034 \\
(1.34)\end{array}$ & $\begin{array}{c}0.138 \\
(2.56)^{* *}\end{array}$ & $\begin{array}{c}-0.032 \\
(1.3)\end{array}$ & $\begin{array}{c}0.158 \\
(2.97)^{* * *}\end{array}$ \\
\hline bankcrisis $_{\mathrm{i}}$ & $\begin{array}{c}-1.257 \\
(4.74)^{* * *}\end{array}$ & $\begin{array}{l}-0.765 \\
(2.31)^{* *}\end{array}$ & $\begin{array}{c}-1.156 \\
(3.91)^{* * *}\end{array}$ & $\begin{array}{c}-0.949 \\
(2.81)^{* * *}\end{array}$ \\
\hline bankcrisis $_{j}$ & $\begin{array}{l}0.043 \\
(0.29)\end{array}$ & $\begin{array}{c}0.227 \\
(0.7)\end{array}$ & $\begin{array}{l}0.032 \\
(0.21)\end{array}$ & $\begin{array}{l}0.229 \\
(0.72)\end{array}$ \\
\hline \# obs. & 900 & 899 & 900 & 899 \\
\hline adjm. factor & 0.5 & 0.55 & 0.5 & 0.54 \\
\hline $\operatorname{adj.} R^{2}$ & 0.21 & 0.12 & 0.22 & 0.13 \\
\hline
\end{tabular}

Notes: see Table 7. 
Table 14: Basic Regression Results: Subsamples

\begin{tabular}{|c|c|c|c|c|}
\hline & \multicolumn{2}{|c|}{ excl. EMU country pairs } & \multicolumn{2}{|c|}{ excl. US } \\
\hline & 1997 & 2001 & 1997 & 2001 \\
\hline & $(1)$ & (1) & $(1)$ & $(1)$ \\
\hline \multirow[t]{2}{*}{$\mathrm{W}_{\mathrm{j}}^{*}$} & 0.092 & 0.161 & 0.085 & 0.155 \\
\hline & $(13.84)^{* * *}$ & $(14.87)^{* * *}$ & $(15.37)^{* * *}$ & $(15.13)^{* * *}$ \\
\hline \multirow[t]{2}{*}{$\operatorname{logdistance}_{\mathrm{ij}}$} & -0.313 & -0.444 & -0.261 & -0.436 \\
\hline & $(5.08)^{* * *}$ & $(4.88)^{* * *}$ & $(5.37)^{* * *}$ & $(5.28)^{* * *}$ \\
\hline \multirow[t]{2}{*}{ samelegor $_{\mathrm{ij}}$} & 0.529 & 0.691 & 0.386 & 0.672 \\
\hline & $(5.44)^{* * *}$ & $(4.08)^{* * *}$ & $(4.91)^{* * *}$ & $(4.35)^{* * *}$ \\
\hline \multirow[t]{2}{*}{$\operatorname{logdcredit}_{i}$} & 0.443 & 0.119 & 0.417 & 0.145 \\
\hline & $(3.22)^{* * *}$ & $(0.54)$ & $(3.40)^{* * *}$ & $(0.71)$ \\
\hline \multirow[t]{2}{*}{$\operatorname{logdcredit}_{\mathrm{j}}$} & 0.294 & 0.242 & 0.183 & 0.201 \\
\hline & $(2.55)^{* *}$ & $(1.34)$ & $(1.91)^{*}$ & $(1.20)$ \\
\hline \multirow[t]{2}{*}{ restrict $_{\mathrm{i}}$} & 0.169 & -0.182 & 0.075 & -0.15 \\
\hline & $(1.35)$ & $(1.16)$ & $(0.72)$ & $(1.02)$ \\
\hline \multirow[t]{2}{*}{ restrict $_{j}$} & 0.064 & -0.011 & 0.096 & -0.023 \\
\hline & $(0.62)$ & $(0.08)$ & $(1.15)$ & $(0.17)$ \\
\hline \multirow[t]{2}{*}{$\operatorname{hrar}_{\mathrm{ij}}$} & 0.297 & -1.757 & 0.448 & -1.668 \\
\hline & $(1.47)$ & $(4.72)^{* * *}$ & $(2.91)^{* * *}$ & $(5.39)^{* * *}$ \\
\hline \multirow[t]{2}{*}{$\operatorname{rcorr}_{\mathrm{ij}}$} & 1.915 & 14.224 & 1.747 & 14.263 \\
\hline & $(0.92)$ & $(1.12)$ & $(1.03)$ & $(-1.24)$ \\
\hline \multirow[t]{2}{*}{ gdpgrowth $_{j}$} & -0.03 & 0.105 & -0.032 & 0.109 \\
\hline & $(1.11)$ & $(2.19)^{* *}$ & $(1.52)$ & $(2.48)^{* *}$ \\
\hline \multirow[t]{2}{*}{ bankcrisis $_{\mathrm{i}}$} & -1.274 & -0.684 & -1.018 & -0.551 \\
\hline & $(4.74)^{* * *}$ & $(2.28)^{* *}$ & $(4.60)^{* * *}$ & $(1.95)^{*}$ \\
\hline \multirow[t]{2}{*}{ bankcrisis $_{j}$} & 0.090 & -0.011 & 0.087 & -0.038 \\
\hline & $(0.6)$ & $(0.04)$ & $(0.70)$ & $(0.14)$ \\
\hline \# obs. & 843 & 916 & 863 & 955 \\
\hline adjm. factor & 0.47 & 0.51 & 0.48 & 0.52 \\
\hline $\operatorname{adj} . R^{2}$ & 0.22 & 0.12 & 0.26 & 0.13 \\
\hline
\end{tabular}

Notes: see Table 7. 
Table 15: Basic Regression Results, Subsamples

\begin{tabular}{|c|c|c|c|c|}
\hline & \multicolumn{2}{|c|}{ excl. UK } & \multicolumn{2}{|c|}{ excl. Japan } \\
\hline & $\begin{array}{c}1997 \\
(1) \\
\end{array}$ & $\begin{array}{c}2001 \\
(1) \\
\end{array}$ & $\begin{array}{c}1997 \\
(1) \\
\end{array}$ & $\begin{array}{c}2001 \\
(1) \\
\end{array}$ \\
\hline $\mathrm{W}_{\mathrm{j}}^{*}$ & $\begin{array}{c}0.085 \\
(15.37)^{* * *}\end{array}$ & $\begin{array}{c}0.155 \\
(15.13)^{* * *}\end{array}$ & $\begin{array}{c}0.091 \\
(13.44)^{* * *}\end{array}$ & $\begin{array}{c}0.167 \\
(14.77)^{* * *}\end{array}$ \\
\hline $\operatorname{logdistance}_{\mathrm{ij}}$ & $\begin{array}{c}-0.261 \\
(5.37)^{* * *}\end{array}$ & $\begin{array}{c}-0.436 \\
(5.28)^{* * *}\end{array}$ & $\begin{array}{c}-0.321 \\
(5.47)^{* * *}\end{array}$ & $\begin{array}{c}-0.548 \\
(6.03)^{* * *}\end{array}$ \\
\hline samelegor $_{i j}$ & $\begin{array}{c}0.386 \\
(4.91)^{* * *}\end{array}$ & $\begin{array}{c}0.672 \\
(4.35)^{* * *}\end{array}$ & $\begin{array}{c}0.528 \\
(5.65)^{* * *}\end{array}$ & $\begin{array}{c}0.829 \\
(4.96)^{* * *}\end{array}$ \\
\hline $\operatorname{logdcredit}_{\mathrm{i}}$ & $\begin{array}{c}0.417 \\
(3.40)^{* * *}\end{array}$ & $\begin{array}{c}0.145 \\
-0.71\end{array}$ & $\begin{array}{c}0.417 \\
(3.07)^{* * *}\end{array}$ & $\begin{array}{c}-0.115 \\
(0.50)\end{array}$ \\
\hline $\operatorname{logdcredit}_{j}$ & $\begin{array}{l}0.183 \\
(1.91)^{*}\end{array}$ & $\begin{array}{l}0.201 \\
(1.29)\end{array}$ & $\begin{array}{c}0.347 \\
(3.03)^{* * *}\end{array}$ & $\begin{array}{l}0.288 \\
(1.53)\end{array}$ \\
\hline restrict $_{i}$ & $\begin{array}{l}0.075 \\
(0.72)\end{array}$ & $\begin{array}{l}-0.150 \\
(1.02)\end{array}$ & $\begin{array}{l}0.119 \\
(0.96)\end{array}$ & $\begin{array}{c}-0.076 \\
(0.45)\end{array}$ \\
\hline restrict $_{j}$ & $\begin{array}{l}0.096 \\
(1.15)\end{array}$ & $\begin{array}{c}-0.023 \\
(0.17)\end{array}$ & $\begin{array}{l}0.120 \\
(1.16)\end{array}$ & $\begin{array}{c}-0.037 \\
(0.24)\end{array}$ \\
\hline $\operatorname{hrar}_{\mathrm{ij}}$ & $\begin{array}{c}0.448 \\
(2.91)^{* * *}\end{array}$ & $\begin{array}{c}-1.668 \\
(5.39)^{* * *}\end{array}$ & $\begin{array}{c}0.571 \\
(3.02)^{* * *}\end{array}$ & $\begin{array}{c}-2.150 \\
(6.24)^{* * *}\end{array}$ \\
\hline $\operatorname{rcorr}_{\mathrm{ij}}$ & $\begin{array}{l}1.747 \\
(1.03)\end{array}$ & $\begin{array}{c}14.263 \\
(1.24)\end{array}$ & $\begin{array}{l}1.659 \\
(0.81)\end{array}$ & $\begin{array}{c}11.128 \\
(0.85)\end{array}$ \\
\hline gdpgrowth $_{j}$ & $\begin{array}{c}-0.032 \\
(1.52)\end{array}$ & $\begin{array}{c}0.109 \\
(2.48)^{* *}\end{array}$ & $\begin{array}{c}-0.037 \\
(1.41)\end{array}$ & $\begin{array}{c}0.127 \\
(2.61)^{* * *}\end{array}$ \\
\hline bankcrisis $_{i}$ & $\begin{array}{c}-1.018 \\
(4.60)^{* * *}\end{array}$ & $\begin{array}{l}-0.551 \\
(1.95)^{*}\end{array}$ & $\begin{array}{c}-1.231 \\
(4.56)^{* * *}\end{array}$ & $\begin{array}{c}-0.962 \\
(2.94)^{* * *}\end{array}$ \\
\hline bankcrisis $_{j}$ & $\begin{array}{l}0.087 \\
(0.70)\end{array}$ & $\begin{array}{l}-0.038 \\
(0.14)\end{array}$ & $\begin{array}{c}-0.028 \\
(0.16)\end{array}$ & $\begin{array}{l}0.076 \\
(0.24)\end{array}$ \\
\hline \# obs. & 863 & 955 & 863 & 955 \\
\hline adjm. factor & 0.48 & 0.52 & 0.48 & 0.53 \\
\hline adj. $R^{2}$ & 0.26 & 0.13 & 0.22 & 0.13 \\
\hline
\end{tabular}

Notes: see Table 7. 


\section{Variable Descriptions and Data Sources}

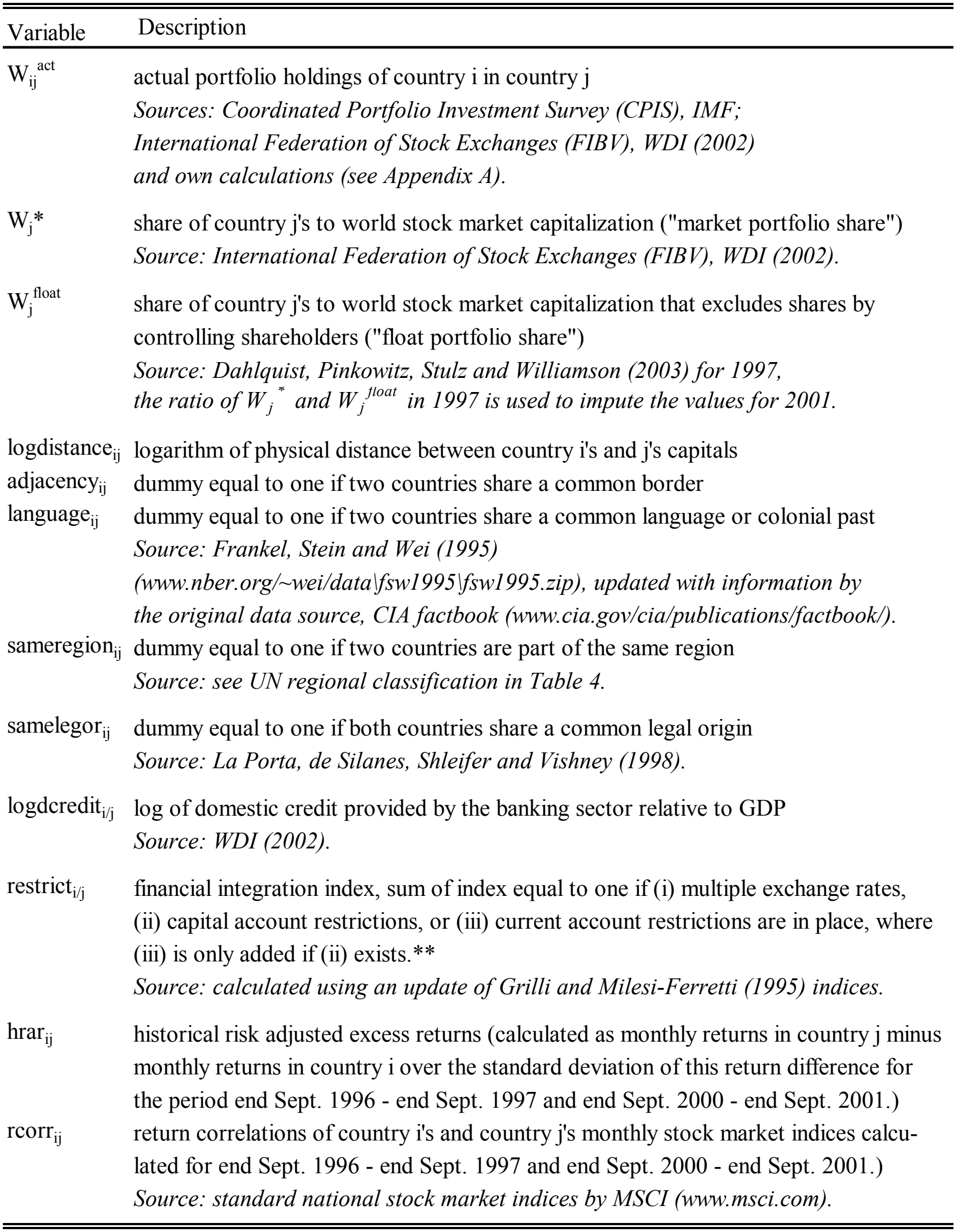

*) I would to thank Axel Dreher for sharing his update.

**) Restrictions on current account have been included because current account transactions can be used to (partially) evade restrictions on capital transactions (if these are in place). 


\section{Discussion Paper Series}

Mannheim Research Institute for the Economics of Aging Universität Mannheim

To order copies, please direct your request to the author of the title in question.

\begin{tabular}{|c|c|c|c|}
\hline Nr. & Autoren & Titel & Jahr \\
\hline $48-04$ & $\begin{array}{l}\text { Christina Benita } \\
\text { Wilke }\end{array}$ & $\begin{array}{l}\text { Ein Simulationsmodell des Rentenversiche- } \\
\text { rungssystems: Konzeption und ausgewählte } \\
\text { Anwendungen von MEA-PENSIM }\end{array}$ & 04 \\
\hline $49-04$ & $\begin{array}{l}\text { Axel Börsch-Supan, } \\
\text { Alexander Ludwig } \\
\text { und Anette Reil-Held } \\
\end{array}$ & $\begin{array}{l}\text { Hochrechnungsmethoden und Szenarien für } \\
\text { gesetzliche und private Renteninformationen }\end{array}$ & 04 \\
\hline $50-04$ & Axel Börsch-Supan & $\begin{array}{l}\text { From Public Pensions to Private Savings: The } \\
\text { Current Pension Reform Process in Europe }\end{array}$ & 04 \\
\hline $51-04$ & Axel Börsch-Supan & $\begin{array}{l}\text { Gesamtwirtschaftliche Folgen des } \\
\text { demographischen Wandels }\end{array}$ & 04 \\
\hline $52-04$ & Axel Börsch-Supan & $\begin{array}{l}\text { Mind the Gap: The Effectiveness of Incentives to } \\
\text { Boost Retirement Saving in Europe }\end{array}$ & 04 \\
\hline $53-04$ & Joachim Winter & & 04 \\
\hline $54-04$ & Axel Börsch-Supan & $\begin{array}{l}\text { Aus der Not eine Tugend - Zukunftsperspektiven } \\
\text { einer alternden Gesellschaft }\end{array}$ & 04 \\
\hline $55-04$ & Axel Börsch-Supan & Global Aging - Issues, Answers, More Questions & 04 \\
\hline $56-04$ & Axel Börsch-Supan & $\begin{array}{l}\text { Was bedeutet der demographische Wandel für die } \\
\text { Wirtschaft Baden-Württembergs? }\end{array}$ & 04 \\
\hline $57-04$ & Hendrik Jürges & $\begin{array}{l}\text { Self-assessed health, reference levels, and } \\
\text { mortality }\end{array}$ & 04 \\
\hline $58-04$ & Alexander Ludwig & $\begin{array}{l}\text { Improving Tatonnement Methods for Solving } \\
\text { Heterogeneous Agent Models }\end{array}$ & 04 \\
\hline $59-04$ & $\begin{array}{l}\text { Frank Betz } \\
\text { Oliver Lipps }\end{array}$ & Stochastic Population Projection for Germany & 04 \\
\hline $60-04$ & $\begin{array}{l}\text { Alexander Ludwig } \\
\text { Alexander Zimper }\end{array}$ & $\begin{array}{l}\text { Investment Behavior under Ambiguity: The Case } \\
\text { of Pessimistic Decision Makers }\end{array}$ & 04 \\
\hline $61-04$ & Barbara Berkel & $\begin{array}{l}\text { Institutional Determinants of International Equity } \\
\text { Portfolios - A County-Level Analysis }\end{array}$ & 04 \\
\hline
\end{tabular}

